\title{
Cahiliye Arap İnancında Putların Yeri
}

\section{Mehmet Mahfuz SÖYLEMEZ*}

\author{
The Position of the Idols in the Pre-Islamic \\ Arabia/Jahiliyyah Religion
}

Citation/@: Söylemez, Mehmet Mahfuz, (2014). The Position of the Idols in the Pre-Islamic Arabia/Jahiliyyah Religion, Milel ve Nihal, 11 (1), 9-50.

Abstract: The faith of pre-IslamicArabian Society is defined as idolatry. In spite of that, there was no any denial about that there is a creative and transcendent god in this belief. The deus otiosus, as a conception of God in the study of religion, is defined as a divine power which had given up intervening with his creature's doings anymore and stepped aside worldly issues. In the frame of this belief, the people, who lived in pre-Islamic Arabian Society, had believed in that they actualize their communication with transcendent god via idols that they composed. they had believed in that they are closing to transcendent god by sacrificing for idols and turning around them and giving respect and honor to them.

Key Words: the Period of the Pre-Islamic Arabia/Jahiliyyah, the Arabian society, idolatry, transcendent God.

Atıf/@: Söylemez, Mehmet Mahfuz, (2014). Cahiliye Arap İnancında Putların Yeri, Milel ve Nihal, 11 (1), 9-50.

Öz: İslam öncesi Cahiliye Arap toplumunun inancı putperestlik olarak tanımlanmaktadır. Ancak bu inanç yaratıcı ve aşkın olan bir tanrının var olduğu

* Prof. Dr., İstanbul Üniversitesi, İlahiyat Fakültesi, İslam Tarihi Anabilim Dalı [mehmet_mahfuz@yahoo.com] 
inancını reddetmemekteydi. Din araştırmalarında deus otiosus olarak tanımlanan bu tanrı anlayışı yeryüzünden çekilmiş ve kullarının dünyevi işlerinden uzaklaşmış ilahi bir gücü ifade etmektedir. Bu inanç çerçevesinde cahiliye Arap toplumu bu aşkın tanrıyla temas kurmayı ihdas ettikleri putlar aracılığıyla gerçekleştirdiklerine inanmışlardır. Bu putlara kurban sunarak, onları tavaf ederek, hürmet ve intiramda bulunarak aşkın tanrıya yaklaştıklarına inanmışlardır.

Anahtar Kelimeler: Cahiliye dönemi, Arap toplumu, putperestlik, aşkın tanrı.

\section{Giriş}

Kur'an'ın ifadesiyle insanoğlu aslında müteal olan bir ve tek Allah'ı kabul etmesi, onu yegâne yaratıcı olarak benimsemesi ve sadece ona ibadet etmesi amacıyla yaratılmış olmasına rağmen, ${ }^{1}$ çoğunlukla bu amaca uygun hareket etmemiş ve çeşitli gerekçelerle değişik varlıklara ibadet etmiştir. İnsanlık Allah'ın çerçevesini çizdiği istikametten uzaklaştıkça yüce yaratıcı onları yeniden hidayete avdet ettirmek için peygamberler görevlendirmiştir. Her gönderilen peygamber, kavminin sürüklendiği esfelu's-safilin çukurundan onu çekip alarak yaratıldığ ahsenu't-takvim hedefine uygun bir düzeye yükseltmiştir. İnsanın hubût ve urûc serüveni, dibe vurduğu bir esnada Hz. Muhammed'in gönderilişi ile yeniden yüzünü yükselişe doğru çevirmiştir. Hz. Muhammed'in getirdiği mesajın bihakkın anlaşılabilmesi, aslında ilk muhataplarının dini anlayışlarının, özellikle de Allah ile ilişkilerinin bilinmesiyle ancak mümkün olacaktır. İşte elinizdeki makale bu konuyu ele almakta olup iki bölümden oluşmaktadır. Makalenin ilk bölümü cahiliye Araplarının putlar hususundaki düşüncesini irdelerken, ikinci bölümü ise Hicaz yarımadasındaki belli başlı putları incelemektedir.

İslam öncesi Arap tarihine baktığımızda Arapların yeknesak bir inanç sistemine sahip olmadıkları, birbirinden farklı gelenekleri benimsedikleri anlaşılmaktadır. Arapların büyük bir kısmı putperest olmakla birlikte içlerinde Yahudi, Hıristiyan, Mecusi, hatta Maniheistlerin bulunduğu da bilinmektedir. Dahası aralarında, özellikle Yemen kökenli Himyer kabilesi gibi gök cisimlerine ibadet edenler de vard1. ${ }^{2}$ Biz bu sistemlerden sadece paganizme yoğunlaşacağımızı ifade etmek isteriz.

\footnotetext{
Bkz. Zariyat 51/56.

Bkz. Muhammed Şükrî el-Âlûsî, Buluğu'l-ereb fi ma'rifeti ahvâli'l-Arab, (neşr: Muhammed Behcet el-Eserî), I-III, Beyrut, ?, II, 237, 240.
} 
Hicaz yarımadasının özü itibariyle Tevhidi düşüncenin merkezi olduğu ve Hz. İbrahim ile İsmail döneminde başlayan bu dini anlayışın uzun süre varlığını koruduğu bilinmektedir. Paganizmin bu bölgede ne zaman başladığı hususu ise tartışmalıdır. Kimi kaynaklarımıza göre Huzaa kabilesinin lideri Amr b. Luhay ile başlamıştır. Hatta bu rivayetlere göre Kâbe'nin yöneticileri olan Cürhüm Kabilesi'nin Mekke' de taşkınlık yapmaya başlaması üzerine ${ }^{3}$ Huzaa kabilesinin lideri Amr b. Luhay, İsmailoğullarının da desteğini alarak onları Mekke'den çıkarmışır. ${ }^{4}$ Daha sonra ağır bir hastalığa yakalanınca Suriye'nin Belka bölgesinde bulunan bir kaplıcaya tedavi olmak üzere gitmiştir. Kaplıcada şifa bulunca yöredeki insanlara dikkat etmiş ve onların putlara taptıkların fark etmiştir. Niçin bu varlıklara ibadet ettiklerini sorunca "Biz bunlar aracılığıyla yağmura ulaşıyor ve düşmana karşı da onlardan yardım talep ediyoruz" cevabını almıştır. Bu cevaptan etkilenen Amr b. Luhay, oradaki putları getirip Hicaz yarımadasının muhtelif yerlerine yerleştirmiş ve halkı bunlara ibadet etmeye çağırmıştır. ${ }^{5}$ Hatta kimi rivayetlere

3 Kaynakların ifadesine göre Cürhümiler Mekke'nin liderliğini üstlendikleri ilk dönemlerde bu kutlu beldeye büyük hizmetlerde bulunmuş olmalarına rağmen zamanla bu misyonlarını terk etmişler ve Mekke ile Kâbe'ye hiç yakışmayan şeyler yapmaya başlamışlardır. Hz. İbrahim' in dinini hafife almışlar, hatta zamanla tebdil etmişler, haramı helalleştirmişlerdi. Hacca gelenlere büyük zulümlerde bulunmuşlar, onları buraya gelmekten soğutmuşlardı. Kâbe'ye tehdiye edilen malları haksız yere zimmetlerine geçirmişlerdi. Hatta onlardan iki kişi (İsâf ve Nâile) Kâbe'nin içinde gayri meşru ilişkiye girmeye dahi cüret edebilmişlerdi. $\mathrm{Bu}$ ve benzeri hadiseler nedeniyle Mekke ve Kâbe'nin imajı ciddi yara almıştır. Geniş bilgi için bkz. Ezrakî, Ahbaru Mekke, Mekke 1965; I, 88-92.

Ezrakî, I, 96.

5 Geniş bilgi için bkz. İbn el-Kelbî (ö:204/819), Putlar Kitabı, (terc: Beyza Düşüngen), Ankara 1969, 27-28; Kurtubî, Ebu Abdullah Muhammed b. Ahmed b. Ebubekir b. Ferah el-Ensarî (ö:671/1272), el-Câmi' li Ahkami'l-Kur'an, I-XX, (tahk: Ahmed elBerdunî ve İbrahim İtfiş), Kahire 1964, VI, 338; Alusî, II, 200 vd. Bu hadise İbn Hişam (ö:218/833) ve diğer bazı kaynaklarda da yer almaktadır. Ancak onlar Amr'ın hastalığından bahsetmez, onun bazı işleri için o bölgeye gittiğini söylerler. Bkz. Siretu İbn Hişam, I-II, (tahk: Mustafa Saka-İbrahim Ebyarî-Abdulhafız Şelebî), Beyrut 1955, I, 77; Ebu'l-Kasım Abdurrahman b. Abdullah es-Suheylî (ö:581/1185), er-Revdu'l-unf fi şerhi's-sireti'n-Nebeviyye li İbn Hişam, I-VII, (tahk: Ömer Abdusselâm), Beyrut 2000, I, 208 vd; Süleyman b. Musa b. Salim el-Kilâî (ö: 634/1236), el-ïktifa fi meğazi Resulillah ve selâseti hulefa', I-II, Beyrut 1420, I, 64; Himyerî, Ebu Abdullah Muhammed (900/1494), Revdu'l-mi'taffi haberi aktar, Beyrut 1980, 517. 
göre Hz. Nuh'un kavminin taptığı putlar da onun tarafından keşfedilip yarımadanın muhtelif yerlerine yerleştirilmiştir. ${ }^{6}$

Kaynaklarımız, Hicaz yarımadası paganizmini bu şekilde başlatmaktadır. Ancak hadiseye biraz yakından bakıldığında olayın bu kadar basit olmadığı anlaşılmaktadır. Zira kanaatimize göre Amr b. Luhay, İsmailoğullarının da desteğini alarak Mekke'nin yönetimine geçtikten sonra, Cürhüm kabilesi döneminde Kâbe ve Mekke'nin sarsılan imajı düzeltmeye karar vermiştir. Onun meşhur hastalığı da bu döneme denk gelmiş olmalıdır. Dolayısıyla Amr b. Luhay Suriye bölgesine giderken yol güzergâhı üzerinde görüştüğü kabilelerin putperest olduklarını ve kendi tanrılarının dışında, diğer putlara pek itibar etmediklerini gördüğü anlaşılmaktadır. Kâbe ve Mekke'nin itibarının da sarsıldığını dikkate alarak bu kabilelerin putlarını da kutsal beyte koymayı önermiştir. Böylece Amr b. Luhay onların tanrılarına bir meşruiyet kazandırırken, Kâbe ve Mekke'ye de saygın bir konum sağlamıştır. ${ }^{7}$

Kuşkusuz Amr b. Luhay'ın bu girişiminin arkasında Mekke'nin ticarî bir merkez olmasının da etkisi vardır. Tevrat'ta da yer aldığı

6 Rivayetlere göre Hz. Nuh'un kavmi tufanda yok olunca putları da selin altında kalmış ve Cidde dolaylarına kadar sürüklenmiştir. Amr b. Luhay döneminde bu putların bazısı ortaya çıkmışır. Amr, Cidde dolaylarına gelerek putların tamamını kumların altından çıkarmak suretiyleyarımadanın muhtelif yerlerine yerleştirmiş ve halkı bunlara ibadete çağırmıştır. [bkz. Yakut el-Hamevî, Şihabuddin Ebu Abdullah (ö:626/1228), Mu'cemu'l-buldân, I-VII, Beyrut 1997, III, 276; Muhammed b. Yusuf es-Salihî eş-Şamî (ö: 942/1535), Subulu'l-huda ve'r-reşâd fi sireti hayri'l-ibâd ve zikri fedailihi ve a'lami nubuvetihi ve ef'alihi ve ahvâlihi fi'l-mebdei ve'lmead, I-XII, (tahk: Adil Ahmed Abdulmevcud-Ali Muhammed Muavvad), Beyrut 1993, II, 177]. Hatta bu mitolojik anlatıyı aktaran kimi kaynaklar Amr b. Luhay'ın, Hz. Nuh'un kavminin Tufan'da yok olan putlarına nasıl ulaştığını kendilerince mantıklı bir kaynağa bağlamış ve hadiseyi Amr'ın var olduğu iddia edilen ve kendisini yönlendirdiği ifade edilen cinine bağlamışlardır. [Bzk. Bureyk b. Muhammed Bureyk el-Umerî, es-Sereya ve'l-buûs en-Nebeviyye Havle el-Medine ve Mekke, Daru İbn el-Cevzî, ? 1996, 292.] Öyle anlaş1lyyor ki bu kaynaklar da bir tek adamın Hicaz yarımadasının tamamını putperest hale getirmesini mantıklı bulmamış ve işi cinlere havale etmişlerdir. Bir tek bu iddia bile söz konusu kurgunun gerçek dışı olduğunu ortaya koymak için kâfi delildir.

7 Cevad Ali'nin de dikkat çektiği gibi Mekkeliler kendi kutsallarına saygı duymak koşuluyla sair kabilelerin tanrılarını kutsamışlardır. Dolaysıyla Diğer putların Mekke'ye taşınmasının arkasında bu putlara sahip olan kabilelerin Mekke'yi kabul etmelerinin sağlanmasının yattığı aşikârdır. Bkz. el-Mufassal: Tarihu'l-Arab kabl el-ìslam, I-XX, Bağdat 2001, XI, 81-82. 
üzere, Mekke kadim dönemlerden beri bir ticaret merkez, idi. Mekkelilere ait kervanlar sadece yarımadada değil, buranın dışına da ticarî emtia taşıyorlardı. Bu kervanların emniyet içerisinde söz konusu bölgelere gidebilmesi için, yörede meskûn bulunan kabilelerin onayının veya desteğinin alınması kaçınılmazdı. Bunun yolu da onların tanrılarına saygı göstermekten geçiyordu. Amr b. Luhay da ticarî yolları açık tutmak amacıyla çevredeki kabilelere ait putları bir şekilde Mekke'ye getirerek Kâbe' nin içerisine yerleştirmiştir. Bu putların 360 kadar oldukları rivayet edilmektedir. ${ }^{8}$ Dolayısıyla Kâbe' nin içerisinde var olan putların her biri aslında Mekke'nin çevresinde yaşayanlarla ticari güzergâh üzerinde meskûn bulunan kabileleri temsil etmektedir. Kuşkusuz Mekke, ataları Hz. İbrahim'in yurdu ve Kâbe "Allah'ın evi" olması hasebiyle, yarımadada ikamet eden Arap kabilelerinin her biri için özel öneme sahipti. Ancak kendi putlarının toplandığı bir merkez haline gelince daha da değer kazanacaktı. Amr b. Luhay tarafından geliştirilen bu yeni sistem Arap yarımadasında paganizm bağlamında bir kırılma oluşturulmuştur. Zira o, Hicaz yarımadasında var olan bütün putlara bir meşruiyet kazandırmakla kalmamış, kabilelerin birbirlerinin putlarına saygı duymalarını, değer verip ibadet etmelerini de sağlamıştır. Kabileler arasında din bağlamında bir hoşgörünün gelişmesini, hatta tanrılar bağlamında bir çatışmazlık halinin kurulmasını da başarmıştır. Şayet bu olmamış olsaydı her kabile kendi tanrısını gerçek ilah kabul edecek; diğer putların bir anlam ifade etmediğini söylemekle kalmayacak bunlara tapan insanları kendi putlarına ram etmek için de bir mücadele başlatacaktı. Amr b. Luhay'ın geliştirdiği bu yeni sistemle her kabilenin tanrısı, diğer kabilenin rabbi kadar değer kazanmış; her kabile kendi tanrısına ibadet etmekle birlikte diğerinin kutsalını da mukaddes kabul ederek sistemin içerisine dâhil etmiştir. Hz. Peygamber İslam dinini tebliğ etmeye başladığı zaman Ebu Cehil başkanlığındaki Mekkelilerin gelerek "Ey Muhammed, gel bir gün sen bizim ilahlarımıza ibadet et, bir gün de biz senin. Şayet senin tanrın yüceyse biz faydalanmış oluruz. Bizimkiler ulu ise sen nimetlenmiş olursun" diyerek onu davet ettikleri şey aslında Mekke' de hâkim olan ve ileri gelenler tarafından benimsenen bu anlayıştan başka bir şey değildir. Muhtemelen bu davet sadece

8 Bkz. Celalettin es-Suyutî, Abdurrahman b. Ebubekir (ö: 911/1505), Hasaisu'lkübra, I-II, Beyrut, ?, II, 307; Cevad Ali, XII, 12. 
Hz. Peygambere de yapılmamıştır. Daha önce farklı söylemlere sahip ve kitleleri etkileyen herkese de yapılmış olmalıdır. Aynı şey Hıristiyanlar için de geçerlidir. Nitekim Hz. Peygamber tarafından Mekke fethedildiğinde Kâbe'nin içerisinde Hz. İsa ve Meryem tasvirlerine rastlanmıştı. Bu tasvirlerin Mekkelilerce buraya konmasının da bunun dışında mantıklı bir izahı yoktur. ${ }^{9}$

Şayet Hz. Peygamber Ebu Cehil ve yanındakiler tarafından sunulan bu öneriyi kabul etmiş olsaydı bu yeni din Mekke'de Kurulu olan söz konusu sistemin bir parçasına dönüşecek ve içi boşaltılmak suretiyle tamamen yok edilecekti. Oysaki Hz. Peygamber "Allah'tan başka ilah yoktur" diyerek İslam'ın var olan bu sistemlere entegre olmayacağını, müstakil ve tek bir ilah olan Allah'ın egemenliğine dayandığını, bu egemenliğin bir başka egemenliği tanımadığını, Allah'ın var olan ilahlardan bir ilah olmayıp, yegâne ve mutlak ilah olduğunu, onun dışında tanrı olarak iddia edilen varlıkların uydurma ve kabul edilebilir olmadıklarını söyleyerek bu öneriyi reddetti. Ancak bu reddedişin bir sonucu olarak Hz. Peygamber ile Müslümanların yaşadıkları baskılar ise bilinmekte olup bu makalenin konusunun da dışındadır.

Yukarıda ifade etmeye çalıştığımız gibi bölgede tapınılan bütün putların her birine yaygın bir meşruiyet kazandıran bu sistemin kurucusu Amr b. Luhay'dır. Bu buluş onu Araplar arasında neredeyse kutsal bir mesabeye yükseltmiştir. Bu hadiseden sonra Amr b. Luhay'ın, yarımada içerisinde hatırası hep diri tutulmuş, dahası ölüm tarihi, takvim başı olarak kullanılmıştır. Kuşkusuz Amr b. Luhay'ı bu denli önemli kılan, onun sadece bütün Arap kabilelerinin, birbirlerinin kutsalların kendi kutsalları olarak da kabul etme sistemini ihdas etmesi değil; aynı zamanda bu anlayışı bir ticarî kazanca da çevirmeyi başarmış olmasıdır. Nitekim bu durum kabileler arasında ticaretin gelişmesine ve özellikle Mekke'nin bir ticaret merkezi olarak önem kazanmasına da katkı sağlamıştır. Öyleyse bu yeni din anlayışının ticari bir yapı kurulmasını sağladığını da söyleyebiliriz. ${ }^{10}$ Kureyş kervanlarının hiçbir kabilenin saldırısına maruz kalmadan yarımadanın tamamında özgür bir şekilde dolaşmalarının arkasında da bu anlayışın önemli etkisi olduğunda hiç kuşku yoktur.

9 Bkz. Ezrakî, I, 165.

10 Konu ile ilgili geniş bilgi için bkz. Cevad Ali, VII, 126; Ahmed İbrahim eş-Şerif, Mekke ve Medine fi Cahiliyye ve ahdi Resulillah (sav), Daru'l-Fikr el-Arabî, ?, 103 vd. 
Kâbe'yi yarımada Arapları için bir penteon merkezine çeviren Amr b. Luhay'ın bu tutumu, onun Arap paganizmini başlatan şahıs olarak anılmasına neden olmuştur. Yoksa kaynakların bir kısmına göre Hübel adlı put, Huzeyl b. Müdrike tarafından getirilip Mekke'ye yerleştirilmiş, hatta bundan dolayı da Huzey'il putu olarak da anılmıştır. Dolayısıyla bu bilgileri esas aldığımızda putperestliğin Hicaz yarımadasında daha önce var olduğu anlaşılmaktadır. ${ }^{11}$ Kaldı ki böylesi önemli bir kırılmanın tek öznesi olarak Amr b. Luhay'ı zikretmek çok da mantıklı olmayacaktır. Zira kabileciliğin bu denli baskın olduğu bir coğrafyada bir kabile reisinin diğer kabilelere paganizm gibi tevhide münafi, yabancı bir anlayışı dayatması çok zor bir ihtimaldir. Hatta kendisine karşı hiçbir tepki olmadan bunu başarma imkânı da zayıftır. Dolayısıyla Amr b. Luhay'ın bölgede var olan putperestliği ticari amaçlarla yeniden biçimlendirdiği varsayımı gerçeğe daha yakın gibi görünmektedir.

Amr b. Luhay'ın geliştirdiği bu yeni sistemde her kabile öncelikli olarak kendi tanrısını ulularken; diğer tanrılara da sistem içerisinde bir yer tanımaktadır. Bu durum Mekkeliler için de geçerlidir. Mekkelilerin birinci putu Hübel'dir. Onların nazarında Hübel'den daha büyük bir put yoktur. ${ }^{12}$ Uzza bile hiyerarşi içinde ondan sonra gelir. Bununla birlikte yarımadanın diğer putlarının tamamına da hürmet gösterirlerdi. Aynı şey diğer kabilelerin tamamı için de geçerlidir.

Kuşkusuz Amr b. Luhay tarafından geliştirilen bu inanç yapılanması Allah'ı sistemin tamamen dışında tutan bir anlayış değildir. Aksine Allah'ı var, bir ve yegâne yaratıcı olarak da kabul ediyordu. Nitekim bununla alakalı olarak Kur'an şöyle demektedir:

De ki: "Eğer biliyorsanız söyleyin: Yer ve yerde bulunanlar kime aittir?" "Allah'ındır" diyecekler. "Öyle ise siz hiç düşünüp ögüt almaz misınız?" de. De ki: "Yedi kat göklerin Rabbi, büyük Arş'ın Rabbi kimdir?" "Allah'tır" diyecekler. “Öyle ise ona karşı gelmekten sakınmaz mısınız?" de. De ki: “Eğer biliyorsanız söyleyin: Her şeyin hükümranlığı elinde

11 Bkz. Abdullah Abdulcebbâr-Muhammed Abdulmünim Hafacî, Kıssatu'l-edeb fi'lHicâz, Mısır ?, 206.

12 Bkz. Muhammed b. İshak (İbn İshak) (ö: 150/767), Siretu İbn İshak, (tahk: Süheyl Zekkâr), Beyrut 1978, 32; Muhammed b. Cerir et-Taberî (ö: 310/922), Tarihu'lumem ve'l-mulûk, I-XI, Beyrut 1387, II, 240. 
olan, kendisi koruyan, kendisine karşı korunulamayan kimdir?" "Allah'tır" diyecekler. “Öyleyse nasıl aldanıyorsunuz?" de." 13

Dahası Cahiliye Arapları sadece Allah'a değil, aynı zamanda ahirete de inanıyorlardı. Onların dini anlayışlarına göre bir şahıs ölünce yıkanır, kefenlenir; kabre konduktan sonra, bineği de getirilip mezarının başına, ayakları ve başı birbirine bağlanmış şekilde terkedilirdi. "el-Beliyye" olarak tesmiye edilen bu hayvancağıa su veya yiyecek verilmez, ölünceye kadar orada tutulurdu. Ölen şahsın dirilişinden sonra bu hayvana bineceğini iddia edilirdi. Şayet mezarının başına bineği bu şekilde bağlanmazsa, kıyamet günü dirildiğinde yaya olarak haşr olacağına inanılırdı. ${ }^{14}$ İbn Habib tarafından aktarılan bu rivayetten açıkça anlaşıldığı gibi cahiliye dönemi insanları Ahirete inandıkları gibi, kıyamete ve hatta haşre de iman ediyorlard.. ${ }^{15}$ Hatta onlar Allah'1 "ilah" veya "rab" olarak kabul ettikleri tüm tanrıların İlahı veya Rabbi, yani "İlahların İlahı" veya "Rablerin Rabbi" olarak görüyorlardı. ${ }^{16}$ Onların ahirete inandıklarını gösteren verilerden bir başkası ise şudur: Yemenliler, özellikle Himyerliler ölülülerini girişinde putların dikildiği veya putlar tarafından korunan mağaralara gömüyorlard1. ${ }^{17}$ Ölümlerinden sonra tanrılarının kendilerine rehberlik yapması, gidecekleri yere emniyet içerisinde gitmeleri ve hiçbir şeyin onlara zarar vermemesi için böyle yapıyorlardı. Bu da onların ölümden sonra bir yaşama inandıklarının; bir başka ifadeyle öte dünyaya yani ahirete iman ettiklerinin delildir.

13 Mü'minun Suresi 23/84-89.

14 Bkz. Ebu Ca'fer Muhammed b. Habib (ö: 245), Kitabu'l-muhabber, (tahk: ilse Lichtenstadter), Beyrut Daru'l-Daru'l-Afâk el-Cedîd, ?, 319.

15 Aslında Cahiliye Arapları için Allah ile kendileri arasında tek aracı putlar değildir. Cinler de Allah ile kullar arasında aracı varlıklar olarak kabul edilmektedir. Nitekim Cahiliye Arapları'nın Hz. Peygamber'i eleştirdikleri zaman "mecnun" olarak tavsif etmeleri de bu bakış açısının bir sonucudur. "Mecnun" derken bizim anladığımız manada "delilik hastalığını" kastetmiyorlardı. Aksine onlar peygamberin son derece anlamll, etkileyici cümlelerini işittiklerinde bu sözlerin birileri tarafından kendisine öğretildiğini ve bunların da ancak cinler olabileceğini iddia ediyorlardı. Keza onlar cin ve meleğin -tabir caizse- Allah'la aynı kumaştan dokunduklarına inaniyorlardı.

16 Bkz. Muhammed İbrahim el-Feyyumî, Tarihu'l-fikr ed-dinî el-Cahilî, Daru'l-Fikr elArabî, Beyrut 1994, 468.

17 Bkz. İbn Hişam et-Ticân fi muluki Himyer, Yemen 1347, 218. 


\section{Putlara İbadet Etmenin Nedenleri}

Allah'1 var ve bir olarak kabul eden, kıyamete ve hatta haşra inanan Cahiliye Arabının putlara neden ibadet ettiğine gelince; kuşkusuz bunun birden fazla nedeni bulunmaktadır. Şimdi bu nedenlere özetle bakalım:

1- Cahiliye Arabı yüce Allah'ı erişilmez kabul ettiği için ona ulaşabilmek amaciyla şefaatçilere ihtiyaç duyuyordu. Kuşkusuz putlara ibadetin en önemli nedeni de işte bu şefaat algısı olmuştur. Put bir taraftan kendisini mabut olarak gören bireyle Allah arasindaki halkayı oluştururken, diğer taraftan da kendisine ibadet eden şahsın Allah nezdindeki koruyucusu olarak tebellür etmektedir. Kur'an'ın Allah katında kendi izni olmaksızın hiç kimsenin şefaat edemeyeceğine dair ayetlerinin tamamı bu anlayışın yanlışlığını anlatmaktadır. ${ }^{18}$

2- Cahiliye Arabının anlayışına göre Putlar Allah nezdinde çok değerlidir. Onları memnun etmek Allah'ın hoşnutluğunu kazanmak anlamina gelecektir. Dolayısıyla Alusî'nin ifadesi ile söyleyecek olursak, putlara taparak aslinda Allah'a ibadet ettiklerine inaniyorlard. ${ }^{19}$ Kur' an' da da ifadesini bulduğu gibi "biz onlara sadece ve sadece bizi Allah'a yaklaştırsınlar diye ibadet ediyoruz" 20 derken de kastettikleri bundan başka bir şey değildir.

3- Cahiliye Araplarına göre her ne kadar Allah erişilmez bir noktada olsa da onun adına yeryüzünde putlar tasarrufta bulunuyordu. Her biri ayrı bir misyon yüklenen bu putlar aslında Allah'ın yeryüzündeki eli mahiyetindeydi. Dolayısıyla Allah'ın bu varlıklar aracılığıyla hayata müdahale ettiğine inanılıyordu. Şöyle ki, her putun önünde fal oklarının bulunduğu torbalar mevcuttu. Birbirinden farklı olan bu torbaların her biri değişik durumlar içindi. Örneğin sefere çıkanlar, içinde "evet" ve "hayır" okları bulunan torba kullanırken; diğer durumlar için içinde "yap", "yapma”, "evet", "hayır", "hayırlı", "şerli", "yavaş", “hızlı" veya üzerinde hiçbir şey yazılı olmayan okların yer aldığı torbalar mevcuttu. O dönemin en önemli konularından biri olan nesebe iltihak için üzerinde "mulsak" veya "serih" yazılı iki ok bulunan torba ayarlanmıştı. Üzerinde "mâ"

\footnotetext{
Bkz. Bakara 2/255.

Bkz. Alusî, II, 197.

Zümer 39/3.
} 
yani "su" yazılı okun bulunduğu torbanın su arayanlar için kullandığı rivayet edilmektedir. Put aracılığıyla Allah'ın emrini öğrenmek isteyen kişi, önce "sadin" olarak isimlendirilen mabet görevlisine gelir ve ona derdini anlatırd. Daha sonra sadin elindeki fal oklar1nın bulunduğu çantayla putun huzuruna gelir ve "Ey Rabbimiz [falanca şu ihtiyacı için sana başvurmaya geldi] hangisi kendisine hayırlı ise onun çıkmasını sağla" der ve çantadaki oklara başvururdu. ${ }^{21}$ Çıkan ok Allah'ın emrini ifade ederdi. Dolayısıyla oku çekenin eğer puta tam bir bağlılığı varsa, bu kararı hiç tartışmadan "Rabbim bana bunu emretti" veya "Rabbim bana bunu yasakladı" der işine veya evine giderdi. ${ }^{22}$ Mesela "serih" çımışsa aileye iltihak edilmesi düşünülen zat ailenin bir parçası haline gelirken; "mulsak" çıkmışsa aileden tamamen uzaklaştııılırdı. "Evet" anlamındaki ok çekilmişse yolculuğa çıkılır; "hayır" oku çekilmişse bu yolculuk ertelenirdi. Hatta aralarında çözemedikleri bir mesele olduğunda bile putlarına başvurmak suretiyle hallederlerdi. ${ }^{23}$

Cahiliye Arabı fal oklarını o kadar çok içselleştirmişti ki rivayetlere göre bu okların Hz. İbrahim ve Hz. İsmail döneminden kaldığına inanıyordu. Nitekim Kâbe'nin içerisinde bu iki kutlu zatı ellerinde fal okları bulunarak resmetmişlerdi. Hz. Peygamber Mekke'nin fethi esnasında Kâbe'nin içerisine girerken gördüğü bu resmi "Allah onları katletsin, İbrahim ve İsmail'in bu oklarla taksim etmediklerini biliyorlar" diyerek eleştirmiştir. ${ }^{24}$ Kuşkusuz putların bu denli hayatın içerisinde olması, Cahiliye döneminde bir yargıçlar sınıfının ve aynı zamanda bir hukuk sisteminin oluşmasına da mani olmuştur. Hatta insanlar arasındaki sorunları çözen bir fıkhın inki-

21 Konu ile ilgili geniş bilgi için bkz. İbn İshak, 32; İbn Habib, Muhabber, 332; Ezrakî, Ebu'l-Velid Muhammed b. Abdullah b. Ahmed (ö: 250/864), Ahbaru Mekke ve ma cae fiha mine'l-âsâr, I-II, (tahk: Ruşti es-Salih), Beyrut, ?, I, 117 vd; Taberî, Tarih, II, 240; Muhammed b. Cerîr et-Taberî, Camiu'l-beyân fi Te'vili'l-Kur'an, I-XXIV, (tahk: Ahmed Muhammed Şakir), Beyrut 2000, IX, 514.

22 Bkz. Bedreddin el-Aynî (ö: 855/1451), Umdetu'l-kari şerh Sahîh el-Buhar̂̂, I-XV, Beyrut, ?, XVIII, 209.

23 Bkz. İbn Hacer el-Askalanî, Fethu'l-Barî şerh sahih el-Buharî, I-XIII, Beyrut 1379, VIII, 277.

24 Bkz. İbn Kesir, Ebu'l-Fida İsmail b. Ömer (ö:774/1372), Tefsiru İbn Kesîr, I-VIII, (tahk: Sami b. Muhammed Sellâme), Daru't-Tayyibe, ?, 1999, III, 24; Hüseyin b. Muhammed b. el-Hasan ed-Diyarbekrî (ö: 966/1558), Tarihu'l-hamis fi ahvâli enfesi'n-nefis, I-II, Beyrut, ?, II, 86. 
şafına duyulan ihtiyacı da ortadan kaldırmıştır. Bununla birlikte Cahiliye Arabının çelişkiler yaşadığı da görülmektedir. Nitekim putuna bu denli bağlı olmasına rağmen, çıkan kararı beğenmemişse kendi bildiğini yapabildiği gibi putuna hakaretler de edebilirdi. ${ }^{25}$

4- Putlara, sadece onların kararını öğrenmek veya kendi yararına karar vermelerini sağlamak için ibadet edilmez, aynı zamanda onların vereceği zarardan beri olmak için de tapılırdı. ${ }^{26}$ Bir başka ifadeyle putlara ya Allah ile kul arasında aracı veya Allah'ın akrabaları olan melek ve cinler ya da kavi şeytanı bulunan varlıklar olarak bakılırdı. Şayet Allah ile kul arasında aracı olarak görülmüşse ibadet edilirken müteal olan Allah'a yakınlaşma hedeflenirdi. Onlara Allah'ın akrabaları olarak bakılmışsa kendilerine sığınılarak hoşnutlukları murad edilmiş olurdu. Şeytanı kavi olarak düşünülmüşse kendilerinden yardım talep edilerek de şerlerinden uzak olunmak istenirdi. ${ }^{27}$ Şeytan ve melek pagan Arapların düşünce dünyasında çok önemli bir yer tutardı. Her putun bir de şeytanı olduğuna inanılırdı. ${ }^{28}$ Ona sığınılarak şeytanından emin olunmak istenirdi. Hz. Peygamber risalet görevine başladığı zaman "bu nasıl peygamber, onunla birlikte bir melek indirilmeli değil mi idi ki, artık onunla beraber bir korkutucu olsa idi?" 29 demeleri onların bu inancının bir yansımasıdır.

\section{Putlara İbadet Şekilleri}

Putlara ibadet şekillerine gelince; kuşkusuz Cahiliye Arabı putlarına değişik şekilde tapardı. Şimdi kısaca bu ibadet şekillerine baka$\lim$.

25 Esed oğulları tarafından babası öldürülen İmriu'l-Kays b. Hucr, babasının öcünü almaya niyetlenir ve Zülhalasa'nın onayını almak için huzuruna gelir. Sadininin yardımıyla önünde bulunan fal okları aracılığıyla ne yapması gerektiğini sorar. Üç kez çekilen fal okunda hep "Esed oğullarına saldırmasının kendisi için hayırlı olamayacağı anlamına gelen" "hayır" oku çıkar. Öç almaya kilitlenmiş olan İmriu'l-Kays onun bu kararını beğenmez: "Fal oklarını kırarak tanrısı olan Zülhalasa'nın yüzüne atmakla kalmaz, aynı zamanda ona "Babamın organını ısırasın. Senin baban öldürülmüş olsaydı beni engellemeye çalışmazdın" diyerek bir de hakaret eder. Bkz. İbn el-Kelbî, 46.

Bkz. Taberî, Tefsir, III, 313.

Bkz. Alusî, II, 197-198.

28 Bkz. Şemsettin Ebu Abdullah Muhammed b. Abdullah b. Osman b. Kaymaz eZehebî (ö: 748/1347), el-Munteka min minhâci'l-i'tidâl fi nakdi kelâmi ehli'r-refdi ve'li'tizâl, (tahk:, Muhyiddin el-Hatib), ?, 524.

29 Furkan Suresi, 25/7. 
1- Hediye takdimi: Yukarıda da ifade ettiğimiz gibi Cahiliye Arabına göre put, Allah ile kullar arasında bir aracıydı. Dolayısıyla putun memnun edilmesi gerekiyordu. Bu memnuniyetin en önemli aracı ise hediye takdimi idi. ${ }^{30}$ Hediye, değişik şekillerde ve zamanlar da takdim edilirdi. Öncelikle hediye takdim etmeyi düşünen zat, bir derdi veya kederi varsa putuna gelir, sadine hediyesini takdim eder ve onun aracılığıyla putundan talepte bulunurdu. Şayet çekilen fal oklarından istediği karar çıkmamışsa bu kararın değişmesi için ertesi gün veya makul bir zaman sonra, daha güzel ve daha göz alıcı başka bir hediye ile yeniden gelir, tanrısının kararını sorardı. Kararı değişinceye kadar bunu tekrar ederdi. Putlara takdim edilen ikinci tür hediye ise teşekkür kabilindendir. Putundan talep ettiği şeyin gerçekleştiğine inanmışsa huzuruna gelir, şükür anlamına gelen hediyesini takdim ederdi.

Kuşkusuz bu hediyelerin tamamı putun sadine, yani onun koruyucusu ile kabilesine kaldığı için en çok onları memnun ederdi.

2- Tavaf: Putlar için yapılan ibadetlerden bir başkası ise tavaftır. ${ }^{31}$ Cahiliye dönemi ibadetlerinin en önemlisi olan tavaf, putların yanı sıra Kâbe'nin, hatta Kâbe'yi temsilen, tavaf amacıyla ortaya konan taşın etrafında da yapılırdı. Kâbe' yi haftada bir kez tavaf etmeyi bir vecibe olarak kabul eden dönemin Arabı, tavaf esnasında Haceru'l-Esved'i de mesh etme geleneğine sahipti. ${ }^{32}$ Mekke'nin dışına çıktığı zaman da haftalık tavaf ibadetini mutlaka yerine getirirdi. Bunu gerçekleştirmek için ya Harem'den aldığı taşın etrafında döner veya bu kutsal mekânı çağrıştıran putunu ortaya koyar ve onun çevresini tavaf ederdi. ${ }^{33}$ Şayet beraberlerinde Harem'den bir taş getirmemişse çevresinde gördüğü en güzel dört taşı seçer, üçünü ocak taşı olarak kullanırken dördüncüsünü Kâbe'yi temsilen koyar, onun etrafında dönerek ibadetini yerine getirirdi. Bu taşa "en-nusub" denilirken, ${ }^{34}$ tavaf etmek için yere koyduğu şey bir put ise ona "sanem" veya "vesen" denilirdi. Bunun etrafında yapılan tavaf ise "ed-

\footnotetext{
Bkz. İbn Hişam, Sire, I, 82; İbn Habib, Muhabber, 319.

Bkz. İbn Hişam, Sire, I, 82; Cevad Ali, XI, 230.

Bkz. İbn Habib, Muhabber, 311.

Bkz. İbnu'l-Kelbi, 26; Süheylî, I, 210; Alusî, II, 200.

Bkz. İbn el-Kelbî, 39; el-Merîi, el-Muhelleb b. Ahmed b. Ebî Sufra (ö:435/1043), elMuhtasaru'l-nasîh fi tezhibi kitabi'l-camii's-sahîh, I-IV, (tahk: Ahmed b. Faris esSelûm), Riyâd 2009, IV, 258; Bedreddin el-Aynî, Umde VIII, 186.
} 
Davvâr" tesmiye edilirdi. ${ }^{35}$ Tavaf esnasında veya tavafını tamamlayınca aynen Haceru'l-Esved'e yaptığı gibi etrafını döndüğü putu ya da taşı mesh ederdi. Ancak bu taşa bir kutsiyet atfetmez, tavafı bitince bir kenara atarak yoluna devam edebilirdi.

Kuşkusuz bu haftalık tavafın dışında bir de şükür tavafı yapılırd1. Ancak bunun belli bir zamanı yoktu. Bir zat dileği ne zaman yerine gelmiş veya ne zaman seferden sağ salim geri dönmüşse o zaman Kâbe veya Lat gibi metaf alanı bulunan mekânlara gider, tavafını yapar, daha sonra evine dönerdi. ${ }^{36}$

3- Kurban: Putlara yapılan bir diğer ibadet şekli ise kurban takdim etmekti. ${ }^{37}$ Putların önemli bir kısmının önünde sunakları bulunurdu. Uzza putunun önündeki sunağa "ğabğab" denilirdi. ${ }^{38}$ Dışardan gelen şahıslar, yedeklerinde getirdikleri kurbanlarını bu sunaklarda tanrıları adına keserler, çoğu zaman akan kanını putlarının üzerine sürerlerdi. ${ }^{39}$ Şayet kurbanını putunun yanında değil de tavaf için ortaya koyduğu ve etrafında döndüğü taşın üzerinde kesmişse bu kurbana "el-atâir"; kurban kesilen sunağa veya kurban taşına ise "el-itr" denilirdi. ${ }^{40}$ Kurban etleri ise orada bulunan fakirler arasında üleştirilirdi.

4- Hac: Özellikle meskûn mahallin dışında kalan putlara yılın belli dönemlerinde hacca gidilirdi. ${ }^{41}$ Mekkeliler, özellikle de Haşimoğulları tarafından Buvâne putuna yapılan hacı buna örnek olarak zikredebiliriz. Kaynaklara göre Haşimoğulları, reisleri Ebu Talib’in liderliğinde, çoluk çocuk hep birlikte yılın belli mevsiminde Buvâne bölgesindeki aynı isimle anılan putu ziyarete giderlerdi. Hz. Peygamber gitmek istemediği için de eleştirilir, hatta ondan dolayı başlarına bir bela geleceğinden korktuklarını söylerlerdi. Puta

\footnotetext{
Bkz. İbn el-Kelbî, 39.

Bkz. Cevad Ali, XI, 227.

Bkz. İbn Hişam, Sire, I, 82; Alusî, II, 197.

Bkz. İbn Hişam, Sire, I, 84; Cevad Ali, XI, 423.

Bkz. Ahmed b. Ali b. Abdulkadir, Takiyuddin el-Makrizî (ö: 845/1441), İmtau'lesma' bima li'n-nebî mine'l-ahvâl ve'l-emvâl ve'l-hafede ve'l-meta', I-XV, (tahk: Muhammed Abdulhamid en-Nemisî), Beyrut 199, I, 351.

40 Bkz. İbn el-Kelbî, 39-40.

41 Bkz. Alusî, II, 197.
} 
gittiklerinde ona kurbanlar takdim eder, yanında birkaç gün de kalırlard. ${ }^{42}$ Benzer şeyleri Lahm, Cüzzam ve Gatafan kabileleri Ukayşir putuna yapıyorlardı. Hatta onlar adı geçen bu putun yanına gelirler, yapılması gereken ritüelleri yerine getirdikten sonra saçlarını tıraş eder, kestikleri bir avuç saça mukabil bir avuç da unu yere dökerlerdi. Fakirlerin bu unları dökülmeden elde etmeğe çabaladığı, hatta saça bulanmış unları toplayarak ekmek haline getirip yedikleri rivayet edilmektedir. ${ }^{43}$ Cahiliye öneminde yeni doğan çocukların kesilen saçlarına mukabil verilen sadakaların da şükür sadakası şeklinde görünmektedir. Hacca gidilen dinî mekânların bir başkası ise Fedek idi. Burada da değişik putların bulunduğu ve onlara ibadet edildiği kaydedilmektedir. ${ }^{44}$

Bunun yanı sıra Hac mevsiminin bitiminde başta Evs ve Hazrec halkı olmak üzere bazı Araplar, kendi kabilelerinin putlarına gidip onları ziyaret eder, kurbanlarını kesip, saçlarını da orada tıraş ederek ihramdan çıkarlardı. Böyle yapmamaları durumunda haclarının kabul olmayacağına inanırlardı.

5- Zekât: Putlar için yapılan ibadetlerden bir diğeri ise esasen zekâta benzer bir sadakadır. Kaynakların ifadesine göre cahiliye dönemi Arabı hasat mevsimi gelip hurmasını veya tahılını hasat ettiğinde Allah ile ona ulaşmak için aracı ittihaz ettiği putunun hakkını ayırır, onu önce ikiye taksim eder, yarısını putu adına diğer yarısını ise Allah adına ayırırdı. Allah'ın hakkının az olmasına çok önem vermez, ancak putun hakkının az olmamasına özel önem atfederdi. Hatta Allah için ayırdığından puta aktardığı da olurdu. Böyle yaparak putunu memnun etmek ve onun Allah'ı memnun etmesini sağlamak isterdi. ${ }^{45} \mathrm{Bu}$ ayırdığ 1 malı da uygun gördüğü yere dağıtırdı.

6- Metaf alanına temizlenmeden girmeme: Putlar tanrisal değere sahip olarak kabul edildiği için hayızlı veya nifaslı kadınların onlara dokunması caiz olarak kabul edilmezdi. Bu durumda olan kadınlar şayet putların bulunduğu mekâna gelmişlerse belli bir uzaklıkta durmak zorunda idiler. Aynı şey metaf alanı için de ge-

\footnotetext{
Bkz. İbn Sa'd, Tabâkatu'l-kubrâ, I-IX, Beyrut, I, 158.

Bkz. İbn el-Kelbî, 46.

Bkz. Cevad Ali, XII, 22.

Bkz. İbn Habib, Muhabber, 331-332.
} 
çerliydi. Bu kabil kadınların metaf alanına girmelerine de caiz olarak bakılmazd1. ${ }^{46}$ Cahiliye döneminde cünüplük de hayız ve nifas gibi bir kirlilik hali olarak görülmüş ve bu nedenle metaf alanına cünüp olarak girilmesinin de caiz olmadığına inandıkları tahmin edilmektedir.

7- Adak: Putlara aynı zamanda adak da adanırdı. ${ }^{47}$ Mekkeli bir şahsin Hübel putunun önünde durup, "Ey Hübel! Eğer sen bana bir çocuk verirsen, ben onu sana bağışlayacağım" demesi bir taraftan bu geleneğin varlığına işaret ederken; diğer taraftan Mekkeli ailelerin kendi çocuklarını Hübel'e hizmete adamaları onun etrafında bir müessesenin oluştuğunu da akla getirmektedir.

8- Telbiye: Putlara yapılan ibadetlerden bir başkası ise telbiyedir. Her kabile kendi putunun hareminde onun etrafında tavaf yaparken putu için geliştirilen telbiyeyi okurdu. Kâbe'de de bu putların önünden geçerlerken aynı telbiyeyi tekrar ederlerdi. Örneğin Lat, Menat ve Uzza için "Lat hakkı için, Uzza hakkı için, onlar yüksek turnalardır. Onların şefaatlerine ümit bağlanabilir. Üçüncüleri olan Menat hakkı için" şeklinde telbiye getirirlerdi. ${ }^{48}$ Cahiliye Arabı adı geçen bu üç putu "gıranik" yani turnalar ya da kuğu kuşu olarak kabul etmekteydiler. ${ }^{49} \mathrm{Kur}^{\prime}$ an onların ibadetleri hakkında "salatları el çırpıp ıslık çalmaktan ibarettir" dediğine göre bunlar putlarının metaf alanlarında onları taklit amacıyla kuş sesleri çıkarıp kanat çırpıyor olmalıdırlar. ${ }^{50}$

İs'af ve Naile putları için geliştirdikleri telbiye ise şu şekilde idi: "Çağrına cevap vererek sana geldik ey Allah, çağrına cevap vererek sana geldik. Senin ortağın yoktur. Bir tek ortağın vardır. Ona da sen egemensin o sana egemen değildir" ${ }^{51}$ derlerdi. Bu telbiye cümlesinden de Cahiliye Arabı'nın putlara, Allah'ın hâkimiyet alanı içerisinde, onun emrinde hareket eden ortakları şeklinde baktıkları anlaşılmaktadır.

\footnotetext{
$46 \quad$ Bkz. İbn el-Kelbî, 38; Yakut el-Hamevî, V, 203.

47 Bkz. Cevad Ali, XI, 423.

$48 \quad$ Bkz. İbn el-Kelbî, 32.

49 Bkz. Ali et-Tantavî (ö:1290/1873), Nihâyetu'l-icâz fi sireti sakini Hicâz, Kahire 1419, 114.

$50 \quad$ Bkz. Enfal Suresi 8/35.

51 Bkz. İbn Habib, Muhabber, 311.
} 
9- Yemin etmek: Cahiliye döneminde Araplar putlar adına yemin ederlerdi. Kâbe adına yemin ettiklerinde ise Kâbe' nin içerisinde putların konduğu yer olan Hicr el-Hatim'e ant içmeyi tercih ederlerdi. ${ }^{52}$

10- Kutsanmak amacıyla dokunmak: Putlara ibadet şekillerinden bir başkası ise onlara dokunarak kutsanmaktı. İbn Hişam'ın verdiği bilgilere göre her şahsın evinde mutlaka bir put bulunurdu. Evinden çıkacağı zaman son yaptığı şey ile evine girdiği zaman ilk yaptığı şey putuna dokunarak kutsanmak olurdu. ${ }^{53}$ Her evde var olan putlara gelince; her kabile mensubunun kendi kabile putunu evine yerleştirdiği tahmin edilmekle birlikte diğer putlardan da istifade ettiği söylenebilir.

11- İsim koyma uygulaması: Cahiliye döneminde insanlar kabile putlarından herhangi birinin adını "onun kulu şeklinde" çocuklarına isim olarak veriyorlardı. Nitekim kaynaklarımızda Abdulyağus, Abduluzza, Abdulmenaf, Abdulmenat, Zeydulmenat, Abduşşaruk gibi erkek isimlerinin yanında Emmetu Uzza gibi kadın isimlerine de rastlanmaktadır. Bireylerin tanrılarının isimlerini çocuklarına vermelerinin arkasında onlara duydukları aşırı ihtiramın yanı sıra onları yüce, ulu; kendilerini ise hakir, zelil ve kul olarak görme düşüncelerinin yattı̆̆ 1 aşikârdır. ${ }^{54}$

\section{Putların Şekilleri}

Putların şekillerine gelince, kuşkusuz cahiliye döneminde tek tip put biçiminden bahsedilemez. Birbirinden değişik olan putları şu şekilde tasnif etmek mümkündür:

1- Ínsan şeklinde olan putlar: Cahiliye döneminde putların önemli bir kısmı insan şeklinde idi. Bunların başında da Kureyş kabilesinin putu olan Hübel gelmektedir. Bir başkası ise Muntabık putudur. İbn Habib'in verdiği bilgiye göre bakırdan yapılmış olan Muntabık'a dokunulduğunda içinden garip sesler geliyordu. Hz. Peygamber'in emriyle yıkıldığı zaman bu garip seslerin sırrı ortaya çıkmış oldu. Zira bu putu yapan uyanık zat, akustiği sağlamak için içine bir kılıç koymuştu. Dokunulduğu zaman kılıç hareket edince doğal olarak bir takım sesler duyuluyordu. Bu sesler put tarafından

\footnotetext{
52 Bkz. İbn Hacer el-Askalanî, Fethu'l-Barî, VII, 159.

53 Bkz. İbn Hişam, Sire, I, 82.

54 Bkz. Cevad Ali, XI, 164; XI, 170.
} 
çıkarılan tanrısal nağmeler olarak anlaşılmış Muntabık'ın yarımada içerisinde bir üne kavuşması sağlanmıştır. ${ }^{55}$ Hele Uzza putu için tasarlanan hile bundan daha etkileyicidir. Nitekim insan heykeli şeklinde olan Uzza, Halid b. Velid tarafından yıkılınca içinden saçları dağınık bir kadın çıkmış, hatta bu kadın putun yıkılmaması için Halid $b$. Velid ile mücadele etmiş ve onun tarafından da öldürülmüştür. Kaynaklarımız bu kadının bir cin olduğunu söyleseler de öyle anlaşılıyor ki Uzza'yı en büyük tanrı haline getirmeye karar verenler, içerisine bir kadının girebileceği gizli bir kapı koymuşlardı. Kadın putun içerisine girdikten sonra zaman zaman gelen ziyaretçilerle konuşarak Uzza'nın var olan şöhretine şöhret katmıştir.

İnsan biçiminde olan putlardan bir diğeri ise Vedd'dir. Erkeklerden uzun boylu bir adam şeklinde olan Vedd'e üst üste iki elbise giydirilirdi. Bu elbiselerden birisi izar, diğeri ise rida olurdu. Kılıç kuşandırılır, omzunda yayı da bulunurdu. Önünde bayraklı bir kargı ile içinde okların bulunduğu ok termesi yani torbası da vard1. ${ }^{56}$

2- Kaya ve taş şeklinde olan putlar: Putların kimisi ise sadece kaya şeklinde idi. Sa'd putu ile Ukayşir putunu buna örnek olarak verebiliriz. Kaya şeklinde olan bu iki puta Kâbe'ye benzer muamele edilir, hatta aynen onun gibi örtülürdü. ${ }^{57} \mathrm{Bu}$ putların yanı sıra, yukarıda tavaf bağlamında verdiğimiz bilgilerden de tebellür ettiği üzere, yolculuk esnasında tavaf zamanı geldiğinde, Cahiliye Arabı herhangi bir taşı seçer onun etrafında dönerek tavafını yapardı. Bu taşa tavaf bitinceye kadar tanrısal bir varlık olarak muamele ederdi. Tavafın bitiminde ise taşı bir kenara atıverirdi.

3- Yatır şeklinde olan putlar: Lat putunu buna örnek olarak verebiliriz. Bilindiği gibi Lat, hacılara un ile kuru üzümü karıştırarak yemek yapan bir adam olup ölünce kabri daha sonra tapılan bir tanrıya dönüştürülmüş̧ür. ${ }^{58}$

4- Kâbe işlevine sahip kült merkezleri ve putlar: Tevhidi düşüncenin merkezi olan Kâbe, aynı zamanda Arap yarımadasında

\footnotetext{
Geniş bilgi için bkz. el-Muhabber, 318.

Bkz. İbn el-Kelbî, 50.

Konu ile ilgili geniş bilgi için bkz. İbn el-Kelbî, 41.

58 Bkz. Beğavî, IV, 308; Carullah ez-Zamahşerî, Ebu'l-Kasım Mahmud b. Amr b. Ahmed (ö: 538/1143), el-Keşşâf an hakaiki cevamidi't-tenzil, I-IV, Beyrut 1407, IV, 422. İleriki sayfalarda bu put hakkında geniş bilgi verilecektir.
} 
putperestliğin şekillenmesi üzerinde de etkili olmuştur. Zira Kâbe, yukarıda da ifade ettiğimiz gibi, Arab'ın vazgeçmediği en önemli ibadet olan tavafın döngü merkezi idi. Dolayısıyla Araplar Mekke dışına çıktıklarında bu ibadetlerini yerine getirirlerken Kâbe'nin misyonunu üstlenecek bir merkeze ihtiyaç duymuşlardır. Bu merkez zaman zaman bir taş, bazen de bir put olmuştur. Kâbe'ye duyulan ihtiyaç bu varlıklarla giderilmeye çalışlırken onların kutsanmasını da intaç etmiştir.

Kâbe'ye benzer ibadet mekânlarının ihdası için duyulan ihtiyacın bir kısmı dinsel olsa da önemli bir kısmının ticari kaygılar taşıdığı da anlaşılmaktadır. Zira Kâbe'nin bir taraftan dinî bir düşüncenin merkezi, öte taraftan da ticari bir odak olduğunu yukarıda dile getirmiştik. Cuheyne kabilesinden Abduddar b. Hudayb'in kendi kabilesine "gelin biz de Kâbe gibi bir mekân edinelim ve ona saygı gösterelim. Böylelikle biz de birçok Arab'ı kendimize çekeriz" demiş olması Kâbe'ye benzer mekânların ihdas edilmesinin arkasındaki mantığı ortaya koymaktadır. ${ }^{59} \mathrm{Bu}$ mekânların en çapıcısı Necranlıların Kebesi ile Yemenlilerin Kâbe'si olarak tesmiye edilen Zülhalasa putudur. Hatta Necranlıların Kâbesi'nde Haceru'l-Esved'e benzeyen ve onunla aynı işlevi gören bir taş dahi vardı. ${ }^{60}$ Biraz sonra daha ayrıntılı bilgi aktaracağımız Zülhalasa ise yapı olarak da Kâbe'nin neredeyse aynisiydı.

5- Melek şeklinde tasvir edilen putlar: Meleklerin varlığına inan Araplar, bunların "Allah'ın kızları" olduğunu iddia ediyorlardı. Bundan dolayı bazı putlarını melek şeklinde tasvir etmişlerdi. ${ }^{61}$ Mekke'nin fethi esnasında Kâbe'nin içinde melek şeklinde çizili olan tasvirlerin bu putlar olması uzak bir ihtimal değildir. ${ }^{62}$ Lat, Menat ve Uzza'yı "Allah'ın kızları" olarak kabul ettikleri bilindiğine göre bu putları da melek olarak tasavvur etmiş olmaları uzak bir ihtimal değildir.

6- Hayvan şekli verilmiş putlar: Paganizmin ortaya çıkışında sevgi kadar korkunun da etken olduğu bilinmektedir. Dolayısıyla insanoğlu bir taraftan sevgiyi abartarak bazı varlıklara taparken, öte taraftan da korkusunu abartarak kimi varlıklara ibadet etmiştir.

9 Bkz. İbn el-Kelbî, 45.

60 Ayrıntılı bilgi için bkz. Cevad Ali, XII, 13.

61 Bkz. İbn Kesîr, Tefsir, VII, 1; Alusî, II, 197.

62 Bkz. İbn Hişam, IV, 55. 
Özellikle doğada yılan, kartal, timsah gibi güçlü ve yırtıcı olan birçok hayvana insanoğlu tarafından ibadet edilmesinin arkasında bu korkunun önemli bir etkisi olmuştur. Bundan dolayı Kur'an sevginin de korkunun da abartılmamasını; aşırı sevgi ve aşırı korkunun bir tek yüce Allah'a yönlendirilmesini, zira yegâne mabudun o olduğunu söylerken Cahiliye Arabının bu bâtıl anlayışını düzeltmeye çalışmaktadır.

İnsan, melek veya hayvan biçiminde olan bu putlar, bir taraftan altın, gümüş ve değerli taşlardan imal edilirken, diğer taraftan ahşaptan da yapılmıştır. Eğer bir put tahta, altın veya gümüşten insan şeklinde oyularak yapılmışsa Arap ona "sanem" derdi. Ancak eğer taş olursa onu "vasen" diye tesmiye ederdi. ${ }^{63}$

7- Put merkezli pazarlar: Putlarla ilgili dikkat çeken noktalardan bir başkası ise bunların tamamının etrafında dönemin büyük pazar veya panayırlarının kurulmuş olduğu gerçeğidir. Hatta öyle anlaşllıyor ki panayırlar, putların bulunduğu bölgelere yapılan hac tarihlerinde kuruluyordu. ${ }^{64}$

Burada üzerinde durulması gereken hususlardan bir diğeri ise her putun etrafında, adına "harem" denilen, bir kutsal alanın ihdas edildiği gerçeğidir. Bu hareme giren, ister insan ister hayvan olsun, güvende olur ve kendisine ilişilmezdi. Putların hareminde savaş olmaz, hatta buradaki bitkilere bile dokunulmazdı. Bazı putlar adına, bulundukları mekânın dişında belli mabetler inşa edilmişti. Örneğin Uzza'nın asıl mekânı Nahle'de olmasına rağmen, Mekke'nin bir vadisinde -Uraz- kendi adına bir mabet inşa edilmiştir. Dolayısıyla özelde mabedin içerisinde genelde ise vadide ağaçların kesilmesi ve avlanılması haram olarak kabul edilmiştir. ${ }^{65}$ Lat'ın asıl mekânı ise Taif olmasına rağmen onun adına Arap Yarımadasının muhtelif bölgelerinde mabetler inşa edilmişti. Bu mabetlerin tamamına putların bizzat kendilerine gösterilen saygı ve ihtiram gösterilir, onlara yapılan ibadetlerin aynısı burada da icra edilirdi. ${ }^{66}$

\footnotetext{
İbn el-Kelbî, 49.

Bkz. Cevad Ali, XIV, 71.

Bkz. İbn el-Kelbî, 33.

Bkz. Cevad Ali, XI, 227.
} 


\section{Putlar ile Kabilesi Arasındaki İlişki}

Burada üzerinde durulması gereken konulardan bir başkası ise putlar ile ona ibadet eden kabileler arasındaki ilişkidir. Bu ilişki son derece ilginçtir, zira yakından bakıldığında kabilelere ait olan putların onların adeta özlerini, hatta neredeyse ruhlarını yansıttıkları görülecektir. Kabileler aidiyet duydukları putla birlikte anılmakla kalmaz, ${ }^{67}$ o putların çocukları olarak kendilerini takdim ederlerdi. ${ }^{68}$ Savaşa çıktıklarında birbirlerine karşı putları ile meydan okudukları gibi zafer durumunda putlarının güçlülüğüne; yenilgi durumunda ise güçsüzlügüne hükmederlerdi. Örneğin Uhud savaşında Müslüman birlikler dağılıp dağa sığındıklarında, Ebû Süfyan meydan okumak için, dağın eteğine kadar gelmiş ve "Yaşasın Hübel, yaşasın Hübel!" 69 deyip Hubel'in adeta gücünü haykırmıştır. Buna karşın Hz. Peygamber "Allah daha yücedir. Ve yüce olmaya daha layıktır" buyurmuştur. ${ }^{70}$ Kuşkusuz, gerek bu hadisede ve gerekse benzeri birçok olayda tebellür ettiği gibi Araplar, aynı zamanda kendi putunu rakip kabilenin düşmanı olarak da görürdü. Bununla birlikte savaşa götürülen putların kendilerine tapanları korumaları gerekirken, onların bu putları muhafaza etmek için verdikleri mücadele ise ironik bir durum olarak karşımızda durmaktadır.

Eğer bir savaş kaybedilmişse, kabilenin tartışma konusu, putlarının kendilerini neden terk ettiği veya neden ihmal ettiği üzerinde yoğunlaşırdı. Genellikle de savaştaki mağlubiyetlerinin temelinde putlarının himayesini kaybetmelerinin yer aldığını ve bu duruma da kendilerinin putlarına gereken saygıyı gösteremediklerinin sebep olduğuna inanılırdı.

Kabileler tapınageldikleri tanrılarını savaş esnasında veya d1şında da yegâne hamileri olarak kabul ederlerdi.71 Dolayısıyla memleketlerinin dışına çıtıklarında bu hamilerini veya onları temsil eden bir şeyi yanlarında taşırlardı. Şayet tüccar ise ve ticari bir sefere çıktıysa, putunu tüketebileceği bir malzemeden imal eder, acıktığı

\footnotetext{
67 Buna $Z u$ Murahhab oğullarını örnek olarak verebiliriz. Bu kabile sahip oldukları Murahhab putuyla anılmıştır. Bkz. İbn Habib, Muhabber, 318.

68 Benu Sa'd yani Sa'doğulları isimlerini tanrıları olan Sa'd'dan almışlardır. Bkz. Cevad Ali, VII, 316.

69 Bkz. İbn el-Kelbî, 36; Ezrakî, I, 117.

70 Bkz. Ezrakî, I, 117.

71 Ukayşir örneği için bkz. İbn Kelbî, 42.
} 
zaman da ayaklarından başlamak suretiyle yerdi. ${ }^{72}$ Eğer putunu yiyip bitirmişse himâyesi için başka bir aracı tayin ederdi. Dolayısıyla Arab’a göre put kutsalı temsil eder ve bu nedenle de kutsaldır. Yoksa cisminin bizzat kendisinin bir kutsiyeti yoktur. Onu yiyebildiği gibi putunun kırılması durumunda atıp yerine kolaylıkla yenisini koyabilirdi. Kırılan putuna yönelik defin gibi özel bir merasim icra etmesi de gerekmezdi.

\section{Putların Sifatları}

Putların sıfatlarına gelince; kuşkusuz Cahiliye Arabına göre putlar, yaratma sıfatı dışında bir tanrıda bulunması gereken özelliklerin tamamına haiz idi. Bunları şöyle sıralayabiliriz.

Put hay'dır. Cahiliye Arabı putların canlı ve hayatta olduğuna inanırdı. Onlara göre putlar, yaşadıkları dünyanın canlı birer parçasıydı. Dolayısıyla bu dünyada tasarrufları devam ediyordu. Bundan dolayı onlara yemek ikram edenler, süt içirenler dahi bulunurdu. ${ }^{73}$ Örneğin Zülhalasa'ya arpa ve buğday ikram edilir, üzerine süt dökülür, yemesi için yiyecek asılırdı. ${ }^{74}$ Hatta Cahiliye Arabı putlarını süsler, ${ }^{75}$ boyunlarına gerdanlıklar takarak göz alıcı hale getirirlerdi. ${ }^{76}$ Dahası Vedd putunda olduğu gibi giydirilen, kılıcı kuşanan, boynunda oku ve yayı boyunlar bile olurdu. ${ }^{77}$ Canlı oldukları için içlerinde evlenenler, çocukları olanlar bile vardı. Muharik putunu buna örnek olarak zikredebilir, Rebia kabilesi onun çocuklarının olduğuna inanır; bu çocuklardan Belc b. el-Muharrik'e bu kabilenin bir kolu olan Anze; Amr b. el-Muharrik'e ise diğer kolları Umeye ile Gufeyle ibadet ederlerdi. ${ }^{78}$

Cahiliye Araplarına göre putlar, razı olur, kızar, nefret eder, merhamet sahibidir, şefkatlidir, esenlik bağışlar, duyar, görür, hikmet sahibidir, ebedidir, hilm sahibidir, âlimdir. Kısacası yukarıda

\footnotetext{
72 Temim kabilesinden bir şair Hanife oğullarının bir açlık ve fakirlik esnasında Tanrılarının cezalandırmasından ve hesaba çekmelerinden korkmadan onları yediğini -ironi ile- aktarmaktadır. Bkz. Hüseyin Atay, 88.

İbn el-Kelbî, 49.

74 Bkz. Feyyumî, 226 vd.

75 Bkz. el-Mesudî, Ebu'l-Hasan Ali b. Hasan (ö: 346/), Ahbaru'z-zaman, Beyrut 1996, 79.

76 Bkz. Bedreddin el-Aynî, Umdetu'l-karî, XIV, 269.

77 Bkz. İbn el-Kelbî, 50.

78 Bkz. İbn Habib, Muhabber, 317.
} 
da ifade ettiğimiz gibi Allah'ın sıfatlarının tamamını taşırlar. ${ }^{79}$ Tek bir farkla, hâlik yani yaratıcı değildirler. Zaten Kur'an'ın ifade ettiği gibi Cahiliye Arabı halik olarak bir tek Allah'a iman ederlerdi.

\section{Sâdin'in Görevleri}

Yukarıda bir vesileyle ifade ettiğimiz gibi her putun bir sâdini olurdu. Sâdinlerin görevlerini şu şekilde özetleye biliriz:

Sâdin yani "sidane" görevini üstlenen şahıs bir din adamı olup toplum içerisinde saygın bir yere sahiptir. Bunlardan bazılarının kehanet görevini üstlendikleri de bilinmektedir. ${ }^{80}$ Dolayısıyla bunlara sıradan put bekçisi olarak bakmamak gerekir. Cahiliye Arabına göre bunlar, putların ve dolayısıyla tanrının kararlarını kendileri aracılı̆̆ıyla diğer insanlara aktardığı şahıslardır. Bu kararlar kuşkusuz fal okları bile bildirilirdi.

Sidane görevini üstlenen şahısların öncelikle bakmakla yükümlü oldukları putlarının güvenliği, bakımı, onarımı, temizliği, şayet üzerinde örtüsü varsa örtüsü ile ilgilenir; putlara takdim edilen hediyeleri muhafaza eder, onların gerekli yerlere dağıtılmasına nezaret ederdi. Takdim edilen kurban etlerinin dağıtımı ile ilgilendiği de olurdu. Putun nezdinde dini kurallara muhalefet edilmemesini sağlar, fal oklarının muhafazası, bakımı ile ilgilenir, ihtiyaç esnasında onları eline alarak putun yanına gelip, önceden dinlediği şahsın sorununu puta bizzat kendisi aktarır ve fal okları çekerek putun kararın ilgili bireye bildirirdi. Uzza gibi içine birilerin girdiği ve put adına konuştuğu şahısların belirlenmesi ve görevlendirilmesi de bu şahıslar tarafından yapıldığını da tahmin etmekteyiz. ${ }^{81}$

Put sidaneliği görevi belli kabilelerin elinde olur ve çoğunlukla o kabilelerin verdiği kararlarla birinden bir diğerine kaydı hayat şartı ile geçerdi. Zaten cahiliye döneminde bir adam üstlendiği görevi ölünceye kadar sürdürürdü. Görevden alınma geleneği yoktu. Kuşkusuz putlar gerek kabileleri ve gerekse sâdinleri için önemli bir gelir kalemi oluştururlardı. Sakif kabilesine mensup şahıslar Hz. Peygambere gelip “Ey Muhammed Müslüman olalım. Amma müsaade et bir yıl daha Lat'tan faydalanalım" demiş olmaları bu durumu açıkça ortaya koymaktadır. Sâdinlerin bazısı fal oklarını

\footnotetext{
Geniş bilgi için bkz. Cevad Ali, XI, 164.

Bkz. İbn Hacer el-Askalanî, Fethu'l-barî, VIII, 277.

Put sidaneliği ile ilgili geniş bilgi için bkz. Cevad Ali, XI, 425 vd.
} 
çektikleri zaman buna karşılık ücret alırlardı. Beğavî bunların fal oku çekmek için yaklaşık 100 dirhem ücret aldıklarını kaydetmektedir $\mathrm{ki}^{82} \mathrm{o}$ günün şartlarında bu ciddi bir rakamdır.

\section{Cahiliye Döneminde Arapların Sahip Oldukları Meşhur Putlar}

Arap yarımadasında yüzlerce putun bulunduğu bilinmektedir. Hz. Peygamber'in Mekke'yi fethettiği esnada bu putlardan 360 tanesinin Kâbe' nin içinde bulunuyor olması sayının ne kadar yüksek olduğunu göstermektedir. Ancak biz burada bu putların tamamını inceleyecek durumda değiliz. Sadece en meşhurlarını özet bir şekilde tanıtarak konunun daha iyi anlaşılmasını sağlamak istiyoruz. Bunlarla ilgili teferruatlı bilgiyi ise Allah izin verirse yakın bir zamanda neşretmeyi düşündüğümüz esere bırakacağız.

1- Lat: Hicaz'ın en etkili putlardan biri kuşkusuz Lat'tır. Kavram olarak "Allah" kelimesiyle aynı kökten türetilmiş olan Lat, dişil bir nitelikte olup "Allah'ın kızı" olarak kabul edilirdi. Her ne kadar Tedmurlular (mö. 1.yy/ms. 634) dönemine kadar uzanan bir geçmişe sahip olsa da ${ }^{83}$ rivayetler onu Taif'e yerleştirmiş, kült merkezinin burası olduğunu iddia etmiştir. Taif dişındaki diğer Lat mabetleri hakkında yeterli bilgi olmasa da burasının bir yatır olduğu anlaşılmaktadır. Bu yatır, Mekke'ye Taif üzerinden hacca gelenlere şehrin bir kenarında oturarak kendi el değirmeniyle ögüttüğü unu kuru üzümle pişirip ikram eden şahsa ait idi. “İnsanlar ikramın kuludur" cümlesinde ifadesini bulduğu gibi, burada karınlarını doyuran şahıslar bahis mevzuu zatı unutmamışlar, vefat edince daha önce hizmet verdiği mekâna gömmüşler ve bunun Lat denilen tanrı olduğunu iddia etmişlerdir. ${ }^{84}$ Üzerine beyaz bir mermer konduğu için de beyaz bir taş olduğu iddia edilen Lat, özelde Taif ve Sakif kabilesi, genelde ise bütün Araplar tarafından tanrı olarak kabul edilmiştir.

Kuşkusuz İslam öncesi dönemde Taif, neredeyse Mekke'ye eş değer bir öneme sahipti. Taif'in bu gücünden istifade etmek isteyen Amr b. Luhay, paganizmi yeniden şekillendirirken burayı da unut-

\footnotetext{
82 Bkz. Ebu Muhammed el-Hüseyin b. Mesud b. Muhammed b. el-Ferrâ el-Beğavî (ö: 510/1116 ), Mealimu't-tenzil fi tefsiri'l-Kur'an, I-V, (tahk: Abdurrezak Mehdi), Beyrut 1420, II, 11.

83 Bkz. Cevad Ali, V, 130.

84 Beğavî, IV, 308; Zemahşerî, IV, 422.
} 
mamıştır. "Allah'ın yazın Taif'te yaşadığını ve Taif'e Lat'ın vücuduna hulûl ettiğini; kışın ise Havran Bölgesinde ise Uzza'ya hulul ettiğini söyleyerek" hem Kureyş'in hem de Sakif'in tanrılarını yüceltmek suretiyle her iki kabileye ayrıcalık tanımıştır. ${ }^{85}$ Kuşkusuz bu durum Kureyş Kabilesi ile Sakif'i denk hale getirdiği gibi Lat'1 neredeyse Kâbe'ye eşit bir hale yükseltmiştir. Buraya da diğer bölgelerden hacca gelenler olduğu gibi Kâbe için var olan müesseselerin tamamı Lat için de oluşturulmuştur. Nitekim kare biçiminde işlenmiş bir taş olan Lat'ın üstüne bir de ev inşa edilmiş, üstü örtülmüştür. Aynen Kâbe gibi sidanesi ve hicabesi de bulunan Lat'ın sidaneliğini Sakif kabilesinin Benu Muattiboğulları yapmaktaydı. ${ }^{86}$ Hatta örtüsü bile Kâbe gibi yılda bir kez ve büyük bir ihtimalle de törenle değiştirilirdi. ${ }^{87}$ Etrafında bir de metaf alanı olan Lat'ın çevresinde tavaf da yapılırdı. Haremi de bulunan Lat, yağmur tanrısı olarak kabul edilmekteydi. Cahiliye döneminde yarımadanın sair bölgeleri sıcaktan kavrulup su bulunmazken buranın serin ve suyunun bol olması, hatta sürekli yağmur alması Lat'a istinat edilirdi. Bu durum Lat'ın ününe ün katmış olmalıdır.

İnsanlar Lat'a çok değer verdikleri için çocuklarına Lat'ın kulları anlaminda "Zeydullat" ve "Teymullat" isimleri vermekteydiler. $\mathrm{Bu}$ put Hz. Peygamber tarafından gönderilen Ebu Süfyan b. Harb ile Muğire b. Şu'be tarafından yıkılmıştır. ${ }^{88}$

Lat mabedinin Taif'in neresinde olduğuna gelince; putlarla ilgili geniş tetebbuata sahip olan İbn Kelbî, Taif'in Müslümanların hâkimiyetine geçmesinden sonra buranın camiye dönüştürüldüğü, hatta caminin minaresinin Lat'a ait olan taşın bulunduğu mekânda yer aldığını söylemektedir. ${ }^{99}$ Şayet bu bilgi doğru ise Müslümanların, karşı oldukları bir inanca ait olsa bile her zaman mabetlere sayg1 göstermiş, onu yine bir mabet olarak kullanmış olduklarını da göstermektedir. Dahası bununla da kendilerinden sonra gelenlere bir mesaj vermiş olmalılar.

\footnotetext{
85 Bkz. eş-Şamî, VI, 196.

86 Bkz. İbn Hişam, Sire, I, 85; İbn Hazm (ö:456/1063), Cemheretu ensâbi'l-Arab, (tahk: Komisyon), Beyrut 1983, 491.

87 Bkz. Cevad Ali, XI, 227.

88 Bkz. İbn Habib, Muhabber, 315. Ayrıca bkz. İbn el-Kelbî, 30-31; Feyyumî, 414.

$89 \quad$ Bkz. İbn el-Kelbî, 31.
} 
2- Menat: Köken itibariyle Semudluların Menvât putuna dayandı̆̆ı sanılan Menât ${ }^{90}$ ile Kenanîlerin kader tanrısı Mena'nın aynı put olduğu tahmin edilmektedir. ${ }^{91}$ Kadim bir tarihe sahip olmakla birlikte İslam tarihi kaynakları tarafından Mekke ile Medine arasında yer alan el-Muşellel bölgesindeki Kudeyd'e yerleştirilmiş ve buranın Menat'in merkezi olduğu iddia edilmiştir. ${ }^{92}$ Ancak Kudeyd'deki Menat'ın Hicaz paganizmi hususunda önemli değişikliklere imza atan Amr b. Luhay'a dayandırılmış olması onun nispeten geç döneme ait olduğunu göstermektedir. Bu da Kudeyd'in Menat'ın asıl merkezi olmadığını, bir Menat mabedi olduğunu akla getirmektedir.

Menat kelimesinin nereden geldiği hakkında da tartışma bulunmaktadır. Cevad Ali bu kavram ile "mina" sözcüğü arasında bir bağ kurarken İz b. Abdusselam, üzerinde çokça kurban kesildiği için bu ismi aldığ 1 kanaatindedir. ${ }^{93}$ Birbirine münafi olmayan bu iki iddianın ikisi de kavramın kökeni hususunda kesin bir bilgi vermekten uzaktır. Kader tanrısı olarak tebellür etmiş olan Menat temelde Ezd kabilesinin tanrısı olup daha çok bu kabilenin iki kolu olan Evs ve Hazrec halkı tarafından ilah olarak kabul edilmiştir. ${ }^{94}$ Hatta onlar Mekke'ye hacca gidince herkesle birlikte vakfeye durur, ancak saçlarını tıraş edip ihramdan çıkmazlardı. Tavaf bittikten sonra Kudeyd'e Menat'ın huzuruna gelirler, onun katında saçlarını tıraş ederek vakfeye durur ve ihramdan çıkarlardı. Böyle yapmamaları durumunda haclarının tamamlanmış olmayacağına inanırlardı. Kureyş de dâhil olmak üzere Arapların neredeyse tamamı tarafından tanrı olarak kabul edilen Menat'ın sidaneliğini ise Ezd kabilesinin kollarından Ğutâridoğulları yapmaktaydı. ${ }^{95}$

Hediyeler takdim edilen, kurbanlar sunulan Menat, çok değerli olarak kabul edildiği için birçok Arap “Menat'ın kulu” anlamına ge-

\footnotetext{
Bkz. Feyyumî, 490.

Bkz. Cevad Ali, XI, 157.

Bkz. İbn Hişam, Sire, I, 85; İbn Habib, Muhabber, 316; Ebu Muhammed İzzuddin Abdulaziz b. Abdusselâm (ö:660/ ), Tefsiru'l-Kur'an, I-III, Beyrut 1996, III, 247.

3 Bkz. İbn Hişam, Sire, I, 85; İbn Habib, Muhabber, 316; İz b. Abdusselâm, III, 247.

Bkz. İbn Hişam, Sire, I, 85.

Bkz. İbn Habib, Muhabber, 3 16; İbn Hazm, 492.
} 
len Abdumenat veya Zeydumenat ismini çocuklarına vermekteydi. ${ }^{96}$ Hicri sekizinci yıla kadar Arapların ibadet ettikleri Menat, bu tarihte Hz. Peygamber tarafından gönderilen Hz. Ali tarafından ortadan kaldırılmış, birçok da ganimet elde edilmiştir. Hatta Hz. Peygamber'in Hz. Ali'ye bağışladığ duğu rivayet edilmektedir. ${ }^{97}$

3- Uzza: Araplar tarafından ibadet edilen meşhur putlardan bir diğeri ise Uzza'dır. Bu ismin hangi kavramdan türediği tartışılsa da Beğavî, Allah'a ait olan el-Aziz sıfatından türetildiği kanaatindedir. ${ }^{98}$ Cahiliye döneminde ona yüklenen misyon bu iddianın yabana atılamayacağını göstermektedir.

Uzza'nın şekil itibariyle sadece üç ağaçtan müteşekkil olduğu kaynaklarda yer almışsa da gerçekte bir heykel idi. Nitekim İbn Habib ve İbn Hazm da durumun böyle olduğunu açıç̧a ifade etmektedirler. Öyle anlaşılıyor ki putun hareminde bulunan ağaçların cesameti ve dönemin geleneğine uygun bir tarzda dilek ağacı olarak kullanılmaları putu gölgede bırakmış ve Uzza'nın üç ağaçtan oluştuğunun iddia edilmesine neden olmuştur. ${ }^{99}$ Üstelik üzerinde bir binanın inşa edildiği anlaşılmaktadır ki Beğavî bu binaya "Beytu'nNahle" denildiğini söylemektedir. ${ }^{100}$ Suriye'nin Nahle bölgesinin kuzeyinde, el-Ğumayr'ın karşısında, Mekke'den Irak'a giderken sağda bir vadide bulunan Uzza, içinden ses işitildiği ifade edilen putlardan biridir. Yukarıda ifade ettiğimiz gibi putun içerisine bir kadın girebiliyor ve gerektiğinde de konuşabiliyordu. Bu durum onun tanrısal bir varlı olduğunun ve konuşabildiğinin iddia edilmesine neden olmuştur.

Arapların çoğunluğu tarafından kutsal kabul edilen Uzza, birçok şahıs tarafından çocuklarına Uzza'nın kulu veya kölesi şeklinde isim olarak da verilmekteydi. Bu isimlerden biri olan Abduluzza en eski Arap isimlerinden biri olarak kabul edilmektedir. Bilindiği gibi

\footnotetext{
96 Bkz. İbn el-Kelbî, 29; Ebû Şame, Ebu'1-Kasım Şihabuddin Abdurrahman b. İsmail b. İbrahim (ö: 665/1266), İbrâzu'l-mânî min birzi'l-emâni fi kıraati's-sab'a, Beyrut, ?, 692.

97 Geniş bilgi için Bkz. İbn el-Kelbî, 30.

98 Bkz. Beğavî, IV, 308.

99 İbn Habib, Muhabber, 315; İbn Hazm, 491.

100 Bkz. Beğavî, IV, 308.
} 
Hz. Peygamber'in amcası Ebu Leheb'in asıl adı Abduluzza idi. ${ }^{101}$ Kureyş Kabilesinin en büyük putu olan Uzza, onların telbiyelerinde de yerini almıştır. Nitekim onlar Kâbe'yi tavaf ederlerken "Lat hakkı için, Uzza hakkı için, onlar yüksek turnalardır. Onların şefaatlerine ümit bağlanabilir. Üçüncüleri olan Menat hakkı için" şeklinde telbiye getirirlerdi. Kureyş Kabilesi ile birlikte onu kutsal kabul eden Araplar Uzza'nın Lat ve Menat ile birlikte Allah'ın kızları olduğuna inanıyorlardı. ${ }^{102} \mathrm{Bu}$ duruma dikkat çeken Kur'an kızlara değer vermeyip erkekleri önemsemelerine göndermede bulunarak "Kızlar bana oğlanlar size mi? Bu ne insafsız bir taksim" diyerek eleştirmektedir. ${ }^{103}$

Kureyş kabilesi, Mekke'nin vadilerinden biri olan Huraz vadisinde, Sukam adındaki bir dağ yarığını Uzza'nın mabedi haline getirmiş ve buraya Kâbe kadar değer vermiştir. Yanında adına Ğabğab denilen bir de sunağı olan Uzza'ya gelen kurbanlar burada kesilir ve hazır bulunan zevat arasında pay edilirdi. Ğabğab, üzerinde yemin edilebilecek kadar kutsal kabul edilirdi. ${ }^{104}$ Amr b. Luhay'ın geliştirdiği sisteme göre Allah kışın burada ikamet eder ve Uzza'ya hulul ederdi. ${ }^{105}$ Etrafında bir de haremi bulunan Uzza'nın üzerinde bir bina mevcut olup çevresinde üç hurma ağacı da vardır. ${ }^{106}$

Hicaz yarımadası Araplarının neredeyse tamamı tarafından kutsal olarak kabul edilen Uzza, en çok da Kureyş kabilesinin tanrısı olarak bilinmektedir. Buraya değişik dönemlerde hac amacıyla ziyaretler düzenleyen Kureyşlilerin yanı sıra Gatafân kabilesi ile ${ }^{107}$ Bahile kabilesi de Uzza'ya ibadet ediyordu. İbn Habib'e göre bu putun sidaneliğini Sırma b. Murre oğullar yaparken, ${ }^{108}$ İbn Kelbî’ye göre ise Benû Suleym kabilesinin bir kolu olan Benu Şeybân b. Câbir yapmaktaydı. ${ }^{109}$ Metaf alanı olan ve tavaf edilen Uzza'ın yanında

\footnotetext{
101 İsim olarak Emmetu Uzza yani Uzza'nın cariyesi şeklinde isimler de kullanılmaktaydı. Bkz. Cevad Ali, XI, 164.

102 Bkz. İbn el-Kelbî, 32.

$103 \mathrm{Bu}$ ayet ve tefsiri ile ilgili geniş bilgi için bkz. Taberî, Tefsir, XXII, 525.

104 Bkz. İbn el-Kelbî, 33; İbn Hişam, Sire, I, 84.

105 Bkz. eş-Şamî, VI, 196.

106 Bkz. Ömer Rıza Kehhâle, mu'cemu kebâilu'l-Arab, I-V, Beyrut 1982, III, 888-889.

107 Bkz. Kehhâle, III, 888-889

108 Bkz. İbn Habib, Muhabber, 315.

109 Bkz. İbn el-Kelbî, 34; İbn Hişam, Sire, I, 84.
} 
"Çağrına cevap vererek sana geldik Ey Rabbimiz, sana geldik, esenlikler olsun sana. Senden daha fazla sevdiğimiz bir şey yoktur" şekline telbiye getirilirdi. ${ }^{110}$

Hz. Peygamber tarafından gönderilen Halid b. Velid, Uzza'nın heykelini kırmış ve hareminde bulunan ağaçları kesmiştir. ${ }^{111}$ Putun içerisinde saçı başı dağınık bir kadının çıktığı ve Halid b. Velid ile mücadele ettiği ancak onun tarafından öldürüldüğü kaydedilmektedir. ${ }^{112}$

4- Hübel (Ha-Ba'1): Bazı oryantalistlere göre güneş tanrısının temsilcisi olarak görülen Hübel, ${ }^{113}$ asılında "Ba' 1 " putudur. Başında bulunan "ha" takısı İbranicedeki harf-i ta'riftir. Ancak kaynaklar1mızda Hübel şeklinde meşhur olduğu için biz de öyle zikretmeyi tercih edeceğiz. Tedmurlular tarafından da tapılmakta olup onlarca "Bel" diye aniliyordu. ${ }^{114}$

Hübel, Kureyş kabilesinin ululadığı en önemli putlardan biri olarak kabul edilmektedir. Kâbe'nin içerisinde yer alan Hübel, kırmızı akikten yapılmış olup, insan şeklinde idi. Sağ kolu kırık olarak Mekke'ye getirilen Hübel'e Kureyş tarafından altından bir kol yaptırılmıştı. İlk kez Huzeyme b. Müdrike tarafından getirildiği için Huzeyme'nin putu olarak da tesmiye edilen Hübel'in önünde fal okları bulunurdu. ${ }^{115} \mathrm{Bu}$ oklara Kureyş kabilesi adına Safvân b. Ümeyye nezaret ediyordu. Bir başka ifade ile sadinliğini yapmaktaydı. ${ }^{116}$ Dolayısıyla Kureyşliler nezdinde Allah'ın muradı, Hübel ve onun önündeki fal okları ile tebellür ediyordu. Kureyş kararlarının tamamını onun önünde çekilen bu fal okları ile belirlerdi. Dolayısıyla Kureyş kabilesi için göğün yeryüzüne açılan kapısı nazarıyla bakılan Hübel'in oklarla verdiği kararlara muhalefet edilmezdi. Abdulmuttalib'in oğlu Abdullah'ı kurban etmeye burada karar verdiği, keza bu kararından ancak burada çekilen oklarla vazgeçmiş

\footnotetext{
110 Bkz. İbn Habib, Muhabber, 311.

111 Bkz. İbn Habib, Muhabber, 315.

112 Bkz. Zemahşerî, IV, 422.

113 Bkz. Cevad Ali, XI, 252.

114 Bkz. Cevâd Ali, V, 130.

115 Bkz. İbn Sa'd, I, 69.

116 Bkz. İbn Abdilberr, İstiab, III, 721.
} 
olduğu düşünüldügünnde ne demek istediğim anlaşılacaktır. ${ }^{117}$ Hübel Mekkelilerin yaşamında o kadar önemli bir yerde duruyordu ki onlardan biri çıktığı seferden döndüğü zaman Kâbe' de yaptığı tavafa onunla ile başlar, tavafı bittikten sonra saçlarını da yine onun huzurunda tıraş ederdi. ${ }^{118}$

Kinane kabilesinin Bekroğulları ile Mâlikoğulları başta olmak üzere bütün boyları tarafından tanrı olarak kabul edilmekte olan Hübel, Mekke'ye gelen hacıların tamamı tarafından kutsal olarak görülürdü. ${ }^{119}$

5- Büvâne: Mekkelilere ait putlardan biri olan Buvâne, Ibn Sa'd'ın verdiği bilgilere göre Buvane adındaki bölgede yer alıyordu. Kureyş kabilesi senede bir kez kendisini ululamak amaciyla düzenli olarak katına gelir, kurbanlar keser, yanında tıraş olur ve bir gün akşama kadar orada i'tikâfa girerdi. Haşimoğullarının en çok önem verdiği tanrılardan biri olduğu anlaşılmaktadır. Nitekim Ebu Talib, kabilenin liderliğini üstlendikten sonar boyun tamamını toplar ve buraya götürmeye çalışırdı. Putlara karşı mesafeli duran Hz. Peygamber buraya gitmek istemediği için onun tarafından azarlandığı, hatta tanrıların hışmını üzerlerine çekeceğinden dolayı da suçlandığı rivayet edilmektedir. Ebu Talib'in bu tavrının peygamberin halaları üzerinde de etkili olduğu, onların da çocuk yaştaki peygambere kızdıkları ifade edilmektedir. Baskılara dayanamayan Hz. Peygamber'in birinde gitmeye karar verdiği, ancak tanımlayamadığı bazı seslerin ikazı ile korkarak oradan kaçtı̆̆ı aktarılmaktadir. ${ }^{120}$

6- İsâf ve Naile: Kureyş'in taptığı putlardan ikisidir. Rivayetlere göre bu iki put, Kâbe'nin içinde gayri meşru ilişkide bulundukları için Allah tarafından taş haline getirilmişlerdir. Daha sonra, insanlar bu şeni' ameliyeyi zihinlerinde tutup ona bulaşmamaları için her ikisini Safa ve Merve tepelerine yerleştirmişlerdir. Zamanla

\footnotetext{
117 Bkz. İbn el-Kelbî, 36; Taberî, Tefsir, IX, 514; Ahmed b. Muhammed b. İbrahim esSa'lebî (ö: 427/1035), el-Keşf ve'l-beyân an tefsiri'l-Kur'an, I-X, (tahk: İmam Ebu Muhammed b. Âşûr), Beyrut 2002, IV, 15; ayrıca bkz. Feyyumî, 419 vd.; 439 vd.

118 Bkz. el-Ezrakî, I, 117.

119 Bkz. İbn Habib, Muhabber, 318.

120 Bkz. İbn Sa'd, I, 158.
} 
asıl neden unutulmuş ve bunlar tanrısal varlıklar olarak kabul edilerek kendilerine ibadet edilmiştir. ${ }^{121}$ Kureyş Kabilesinin İsâf ve Naile'nin yanında bir de telbiyeleri vardı. Telbiyelerinde "Çağrına cevap vererek sana geldik ey Rabbimiz, çağrına cevap vererek sana geldik. Senin ortağın yoktur. Bir tek ortağın vardır. Ona da sen egemensin o sana egemen değildir" diyorlardı..22 Kureyş kabilesine mensup dindar zevat kurbanlarını bu putların yanında keserler, kanlarını da üzerlerine sürerlerdi. ${ }^{123}$ Amr b. Luhay'ın bunlara bereket duası yapılmasını emrettiği rivayetini esas aldığımızda İsaf ve Naile'nin bereket tanrı ve tanrıçası olduğu anlaşılmaktadır. ${ }^{124}$ İsaf ve Naile'nin biri Safa, diğeri ise Merv'e tepesinde duruyordu. İslam dini nazil olduğunda Müslümanlar bunlardan dolayı sa'y yapmamayı düşünmüşler. Ancak Yüce Mevla onların bu düşüncelerinin yanlışlığını "Safa ve Merve Allah'ın şiarlarındandır. Hacca ve Umereye gidenlerin onları tavaf etmesinde kendileri için bir günah yoktur" ayetini nazil kılarak dile getirmiş ve kendilerini bu kararlarından vazgeçirmiştir. ${ }^{125}$

7- Menâf: Hz. Peygamber'in dedesine adını veren bu putun $\mathrm{Ku}$ reyş kabilesinin ululadığı tanrılardan biri olduğu bilinmektedir. Ancak İbnu'l-Kelbî onun nerede olduğunu ve kimin tarafından oraya dikildiğini bilmediğini söylemektedir. ${ }^{126}$ Taberî ile Maverdî ise onun Mekke'nin en büyük putlarından biri olduğu kanaatindedirler. ${ }^{127}$ Ancak Havrân bölgesinde keşfedilen kitabelerde Menâf adına rastlanmış olması bunun kadim tanrılardan biri olduğunu göster-

121 Bkz. İbn Kelbî, 28; İbn Hişam, Sire, I, 82-83; İbn Habib, Muhabber, 311; Bkz. Alusî, II, 201.

Bkz. İbn Habib, Muhabber, 311.

123

Bkz. Hüseyin Atay, “İslam'dan Önce Arap Yarımadasında Putperestlik ve Yay11ışı", Ankara Üniversitesi İlahiyat Fakültesi Dergisi, I-IV: 1957, Ankara 1959, s. 88. Bkz. Taberî, Tefsir, III, 233; İbn Ebî Hatem er-Razî, Ebu Muhammed Abdurrahman b. Muhammed b. İdris b. Münzir et-Temimî (ö: 327/938), Tefsiru'l-Kur'ani'lazîm, (tahk: Es'ad Muhammed et-Tayyîb), Riyad 1419, 267.

126 Bkz. İbn el-Kelbî, 38.

127 Bkz. Taberî, Tarih, II, 254; Ebu'l-Hasan Ali b. Muhammed b. Muhammed el-Maverdî (ö: 450/1058), A'lamu'n-Nubuvve, Beyrut 1409, 192; ayrıca bkz. Yakut el-Hamevî, V, 203. 
mektedir. Bir başka kitabede ise "Menafius" adına denk gelmiş olması bu tanrının Yunan kökenli putlardan biri olabileceğini akla getirmektedir. ${ }^{128}$

8- Ruda': Ruda', Rebia b. Ka'b oğullarına ait bir mabet olup, Hz. Peygamberin emriyle Müstevğir $b$. Rabia $b$. Ka'b tarafından yıkılmiştır. ${ }^{129}$

9-Sa'd: Sa'd, Kinane kabilesi'nin putudur. Rivayetlere göre bu kabileye mensup bir zat onun yanında kurban etmek üzere devesini yedekleyerek getirmiş. Putu gören deve ondan korkup kaçınca adam puta taş atarak "Allah senin ilahlığını kaldırsın develerimi ürküttün" demiştir. ${ }^{130} \mathrm{Bu}$ hadise aslında Cahiliye Arabının düşünce dünyasında putların yerini göstermesi açısından önem arz etmektedir. Zira dikkat edilirse "Allah senin ilahlığını kaldırsın" demekte gerçek hakimiyetin Allah'ta olduğuna itiraf etmekte; kendisi için adına kurban kesilecek kadar önemli olmasına rağmen, gerektiğinde putunu terk edebilmekte, sadece Allah'ı yegane güç sahibi olarak kabul edebilmektedir. Yanı sıra putların ilahlığının da Allah tarafından verildiğine inanmaktadır. Hatta bahis mevzuu adamın bu hadiseden sonra şöyle bir şiir inşat ettiği rivayet edilmektedir:

Biz Sa'd'a bizi birleştirsin diye geldik. Oysaki Sa'd bizi darmadağın etti. Öyleyse biz Sa'd'dan değiliz. Sa'd artık çöldeki kayadan başka bir şey değildir. Ona ne eğri ne de doğru için dua edilir." 131

Vebre oğulları dişında Kudaa kabilesinin tamamı ile Huzeyl Kabileleri de Sa'd putuna ibadet ediyorlard1. ${ }^{132}$

10- Zülhalasa: Zülhalasa'nın üzerinde bir çeşit taç işlenmiş ak bir kaya olduğu, Mekke ile Yemen arasındaki Tabila'da, Mekke'ye yedi gecelik uzaklıkta bulunduğu rivayet edilmektedir. Sidaneliğini Bahila kabilesinden Umame oğullarının yaptığı Zülhalasa, özelde Ezdu Surât, ${ }^{133}$ Hevazin, Becîle, Devs ve Has'am kabilelerinin tanrısı

\footnotetext{
128 Bkz. Feyyumî, 226.

129 Bkz. İbn Hişam, Sire, I, 87.

$130 \quad$ Bkz. İbn el-Kelbî, 41.

131 Bkz. İbn el-Kelbî, 41.

132 Bkz. İbn Habib, Muhabber, 316.

133 Bkz. İbnu'l-Kelbî, Putlar, 40; Yakut el-Hamevî, II, 383; Kehhâle, I, 18.
} 
iken, genelde ise özellikle Yemenli bütün Araplar tarafından kabul görmüştü. ${ }^{134}$

Zülhalasa İslam öncesi dönemde özellikle Has'am kabilesi gibi Yemen kökenli bazı kabiller tarafından Kâbe'nin alternatifi olarak kabul edilmekteydi. Hatta bundan dolayı buraya Yemenlilerin Kâbe'si de deniliyordu. ${ }^{135}$ Bu kabileler Kâbe'nin kutsiyetinden ziyade Zülhalasa'nın mukaddesliğine inanıyorlardı ve ona ibadet ediyorlardı. Hatta bu nedenden dolayı bu kabileler Fil Hadisesi esnasında Ebrehe'nin ordusuna destek vermekle kalmamış, ordunun rehberliğini de yapmışlardı. ${ }^{136}$ Kâbe ile aynı biçimde olan Zülhalasa'nın da bir panteon olduğu ve içerisinde aynen Kâbe'de olduğu gibi çeşitli putların yer aldığı rivayet edilmektedir. Büyük bir ihtimalle bu putlar da Yemenli kabilelerin putlarıydı. ${ }^{137}$

Becile, Has'am, el-Hâris b. Ka'b, Cerem, Zübeyd, el-Ğavs b. Murr b. Udd, Benû Hilâl b. Âmir kabilelerinin de ibadet ettikleri Zülhalasa'nın sidaneliğini ise Benû Hilal b. Âmir yürütmekteydi. Her ne kadar İbn Habîb, Zülhalasa'nın Mekke'ye yaklaşık olarak dört merhale mesafede, burayla Yemen arasinda bulunan elAblâ'da olduğunu ve hicri ikinci asra kadar varlığını koruduğunu o dönemlerde çamaşırhane olarak kullanıldığını söylüyorsa da, ${ }^{138}$ İbnu'l-Kelbî, Zülhalasa putunun olduğu yerde daha sonra Taballa camiinin inşa edildiğini söylemektedir. ${ }^{139}$ Lat putunun bulunduğu mekânın camiye dönüştürüldüğünü düşündüğümüzde İbn Kelbî'nin söylediklerinin daha doğru olabileceği akla gelmektedir.

134 Bkz. İbnu'l-Kelbî, Putlar, 40-41; İbn Hişam, Sire, I, 86 vd; Bedreddin el-Aynî, Umdetu'l-kari, XIV, 269; Zülhalasa ile ilgili geniş bilgi için bkz. Feyyumî, 226 vd.

135 İbnu'l-Kelbî, Putlar, 40; Nevevî, Ebu Zekeriyya Muhyiddin Yahya (ö:676/1277), el-Minhâc fi şerh sahih Müslim b. el-Haccâc, I-XVIII, Beyrut 1392, XVI, 35; Kehhâle, I, 332. Ancak İbn Hişam onun Araplardan bir şahıs olduğunu söylemektedir. Bkz. İbn Hişam, Sire, I, 86.

136 Bkz. M. J. Kister, "Some Reports Concerning Mecca From Cahiliyye to İslam", JESHO, Brill, Leiden 1972, 69.

137 Bkz. Nevevî, Minhâc, XVI, 35.

138 Bkz. İbn Habib, Muhabber, 317.

139 Bkz. İbnu'l-Kelbî, Putlar, 41. 
11- Saide: Ezd kabilesinin tanrılarından biri olan Saide putu, ${ }^{140}$ Uhud bölgesinde yer almakta olup sidaneliğini Benî Aclân kabilesi yürütüyordu. ${ }^{141}$

12- Nesr: Yemen kabilelerinden Himyer'e ait putlardan biridir. İslam öncesi dönemde farklı dinlere bağlı olan Himyerilerin çoğunluğu putperest olup Nesr'e ibadet ediyorlard.. ${ }^{142}$ İbn Habib'e göre, Yemen hükümdarlarına ait Ğumdân kasrında bulunuyor iken, ${ }^{143}$ İbn el-Kelbî'ye göre ise Belha'da yer alıyordu. ${ }^{144}$ İbn Abbas Nesr'in de Yeuk ve Yeğus ile birlikte Hz. Nuh'un kavminin putlarından biri olduğunu söylemektedir. ${ }^{145}$ “Tevrat'ın kendisinden Arap putlarından Neşr" şeklinde bahsettiği kaydedilmektedir. ${ }^{146}$

13- Celsed: Cahiliye döneminde Kinde kabilesinin çoğunluğu putperest olup Hadremevt'te bulunan el-Celsed putuna tapmaktaydi. ${ }^{147}$

14- Ukayşir: Anavatanları Şeher, Necran ve Hicaz'ın bir bölümü olan Kudaa kabilenin putperest olanları el-Ukayşir putuna tapmaktayd1. ${ }^{148}$ Gatafan kabilesi de bu puta inaniyordu. ${ }^{149}$ Keza Ukayşir aynı zamanda Lahm, Cüzâm ve Amile kabilelerinin de tanrısı idi. Kaya şeklinde olan Ukayş'in aynen Kâbe'de olduğu gibi örtündüğü de rivayet edilmektedir. ${ }^{150} \mathrm{Bu}$ kabileler Ukayşir'e hac amacıyla gelirler, yanında saçlarını tıraş ederler, kestikleri bir avuç saç için bir avuç unu yere serperlerdi. ${ }^{151}$

15- Yeğûs: Mezhic kabilesi, müttefikleri ile birlikte Yeğus putuna tapmaktayd.. ${ }^{152}$ Dönemin önemli tanrılarından biri olan Yeğus, önceleri En'am bölgesinde iken Muradoğullarının Beni Ğuteyf kolu tarafından çalınarak memleketleri olan Yemen'in Necrân bölgesine

\footnotetext{
140 Bkz. İbnu'1-Kelbî, Putlar, 40; İbn Hazm, 493; Kehhâle, I, 18.

141 Bkz. İbn Habib, Muhabber, 316-7; İbn Hazm, 493.

142 İbnu'1-Kelbî, Putlar, 29.

143 Bkz. İbn Habib, Muhabber, 317.

144 Bkz. İbn el-Kelbî, 29.

145 Bkz. Taberî, Tefsir, XXIII, 640.

146 Bkz. Cevad Ali, el-Mufassal: Tarihu'l-Arab kabl el-İslam, I-XX, Bağdat 2001, II, 303.

147 Bkz. Kehhâle, 1000.

148 Kehhâle, III, 957.

149 Bkz. Kehhâle, III, 888-889.

150 Bkz. İbn el-Kelbî, 41.

151 Bkz. İbn el-Kelbî, 46.

152 İbnu'1-Kelbî, Putlar, 28; İbn Hazm, 492.
} 
götürmüştür. Muradoğullarının tamamı tarafından tanrı olarak kabul edilmekte olan Yeğus, bu hadiseden dolayı "kendisine sahip olmak için savaşılan tanrılardan biri" olarak tarihe geçmiştir. ${ }^{153}$ Cüreyşlilerin de ibadet ettikleri Yeğus, ${ }^{154} \mathrm{~Hz}$. Nuh'un kavminden kalan putlardan biri olarak bilinmektedir. ${ }^{155}$

16- Yeuk: Hemedan ile Havlan'ın tanrısı olan Yeuk İbn Habib'e göre Erhab bölgesinde bulunuyor iken; ${ }^{156}$ İbn kelbi'ye göre ise Sana'nın Mekke tarafında şehre iki gecelik mesafedeki Hayvân'da yer almaktayd. ${ }^{157}$ Yemenliler, özellikle de Hemdan kabilesinin tanrılarından biri olan Yeuk'un da aynen Yeğus gibi, ${ }^{158} \mathrm{~Hz}$. Nuh döneminden kalan putlardan biri olduğu rivayet edilmektedir. ${ }^{159}$

17- Fils: Fils, Tay kabilesine ait putlardan biridir. Bilindiği gibi bu kabilenin önemli bir kısmı İslam öncesi dönemde Hıristiyandı. Liderleri Adiyy b. Hatem et-Taî, boynundaki haçla birlikte Medine'ye gelip İslam dinini kabul etmiş̧ir. ${ }^{160}$ Tay kabilesinin putperest olan kismı ise bu puta yani Fels'e tapiyordu. ${ }^{161}$ Resulullah (s.a.v.) 9/630 yılda Fils'i yıkmak için Ali b. Ebî Talib komutasında elli kişilik bir kuvvet göndermiş, Hz. Ali bahis mevzuu putu yıkarak bir miktar ganimetle birlikte Medine'ye dönmüştü. ${ }^{162}$ Necd bölgesinde bulunan Fils'in sidaneliğini Bûlânoğulları yapmaktaydı. ${ }^{163}$ Fels'in etrafında da bir mabed vard. ${ }^{164}$ İnsan şeklinde olan Fils'in kırmızı burunlu olduğu ve Tay kabilesi'nin ona hediyeler takdim edip kurbanlar sunduğu rivayet edilmektedir. ${ }^{165}$

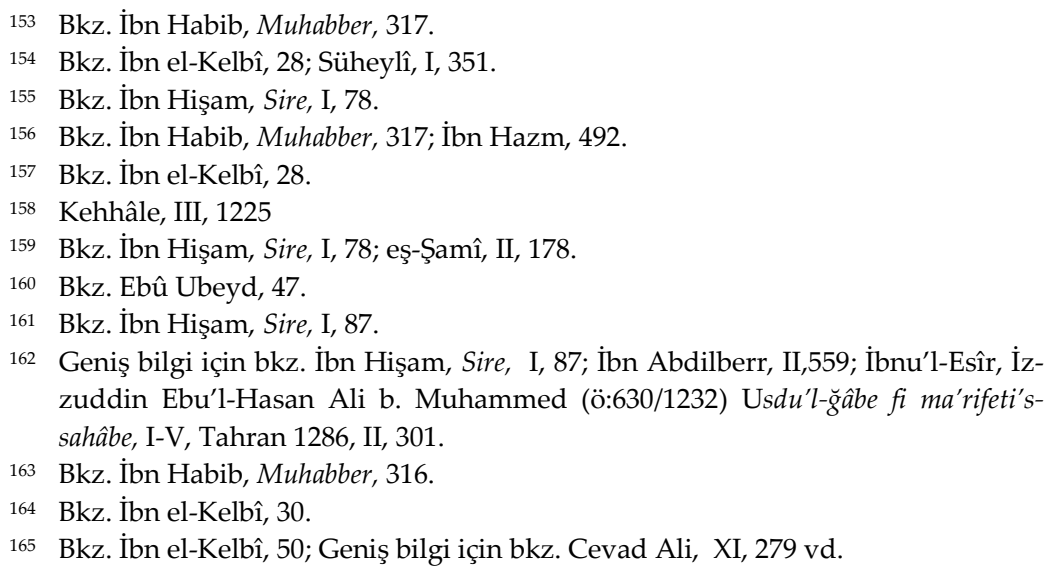


18- Nuhb: Medine ile Vadiu'l-Kurâ arasında ikamet etmekte olan Müzeyne kabilesinin putudur. ${ }^{166}$

19- Bussa': Kâbe'ye benzeyen yapılardan biri olan Bussa', Gatafan kabilesine ait olup etrafında bir metaf alanının bulunduğu kaydedilmektedir. ${ }^{167}$

20- Zülkaabât: Anavatanları Yemame, Bahreyn ve Irak Sevad'1 olan ünlü Bekr b. Vâil kabilesinin önemli bir kısmının İslam öncesi dönemde Hıristiyan olduğu bilinmektedir. Ancak bununla birlikte kabilenin içerisinde putperestler olanlar da vardı ve bu putperestler "Zülkaabât" ile "Muharik" adındaki putlara ibadet ediyorlardı. ${ }^{168}$ Bu puta Bekr b. Vail ile birlikte İyâd ve Tağlib kabilesi de tapıyordu. ${ }^{169}$

21- el-Lebba: Abdulkays kabilesine ait olan bu put Muşakkar'da yer aliyordu. ${ }^{170}$

22- Cihâz: Ukkaz bölgesinde Ahtal Dağı'nın eteklerinde bulunup bu put, Hevazîn ile Muhariboğullarına ait idi. Sidaneliğini ise Avfoğulları yapmaktaydı. ${ }^{171}$

23- Suvâ': Nu'man bölgesinde olup Kinâne, Hüzeyl, Müzeyne ve Amr b. Kays b. Aylân kabilelerinin tanrısıdır. Sidaneliğini Hüzeyl kabilesinden Sahineoğulları yapmaktaydı. ${ }^{172}$ İbn el-Kelbı̂́ye göre Yanbu' bölgesinin Ruhat yöresinde yer alıyordu. Sidaneliğini ise Lihyân oğulları yapmaktaydı. ${ }^{173}$ Cevad Ali, Hemedanlıların da onu tanrı olarak kabul ettiklerini söylemektedir. ${ }^{174}$

166 Bkz. Kehhâle, III, 1083-1084.

167 Bkz. Kehhâle, III, 888-889.

168 Bkz. Kehhâle, I, 98.

169 Bkz. İbn Hişam, Sire, I, 88.

170 Bkz. Kehhâle, II, 726-727. Ayrıca bkz. Cevad Ali, XI, 284. İbn Hazm Zu Lebbâ şeklinde kaydetmektedir. Bkz. İbn Hazm, 493.

171 Bkz. İbn Habib, Muhabber, 315.

172 Bkz. İbn Habib, Muhabber, 316; İbn Hazm, 492; Yakut el-Hamevî, III, 276; Kehhâle, III, 1225.

173 Bkz. İbn el-Kelbî, 28.

174 Bkz. Cevad Ali, XI, 258. 
24- Şumes: Temim kabilesinin putuydu. Ud Kabilesinin bütün kolları da ona ibadet ediyorlardı. Sideneliği ise Evs b. Muhaşen tarafından yürütülüyordu. Hz. Peygamber'in emriyle ashaptan Hind b. Hale ile Safvân b. Esîd tarafından ortadan kaldırılmıştır. ${ }^{175}$

25- Vedd: Vebreoğullarının tanrısıdır. Dummetu'l-Cendel tarafında bulunuyordu. Sidâneliğini Kelb kabilesinden Ferafisa b. elAhves oğulları yürütüyordu. ${ }^{176}$ Vedd aynı zamanda Kelb kabilesinin de tanrısıydı. ${ }^{177}$ İnsan şeklinde olan Vedd, erkeklerden uzun boylu bir adamın heykeli idi. Üst üste iki elbise giydirilirdi. Bu elbiselerden birisi izar, diğeri ise rida olurdu. Kılıç kuşandırılır, omzunda yayı da olurdu. Önünde bayraklı bir kargı ile içinde okların bulunduğu ok termesi yani torbası yer alırdı. ${ }^{178}$ Vedd'in Hz. Nuh'un kavminin taptığ putlarından biri olduğu rivayet edilmektedir. ${ }^{179}$ Kadim tanrilardan biri olduğu bilinen Vedd Mainliler'in (mö: 1400650) de tanrısiydi. ${ }^{180}$

26- Zülebbâ: Muşakkar bölgesinde olup Abdulkaysoğullarının tanrısıdır. Sidaneliğini onlardan Benû Âmir yürütmekteydi. ${ }^{181}$

27- Muharrik: Bekr b. Vâil kabilesinin tanrılarından biridir. ${ }^{182}$ Bekr b. Vâil ile Rebia kabilesinin diğer boyları tarafından ibadet edilen el-Muharrik, Selmân bölgesinde yer alıyordu. Rebia kabilelerine göre Muharrik'in çocukları vardı. Bundan dolayı her bir boy bu çocuklardan birine ibadet ediyordu. Anze, Belc b. el-Muharrik'e; Ümeye ile Ğufeyle ise Amr b. el-Muharrik'e tapiyordu. Muharrik'in Sidaneliğini ise Benû Aclun oğullarından Benu Esved tarafından yapilmaktayd.. ${ }^{183}$

28- Zübeyh: Kinde kabilesinin tanrısı olup Hadramevt bölgesindeki Nuceyr'de yer alıyordu. ${ }^{184}$

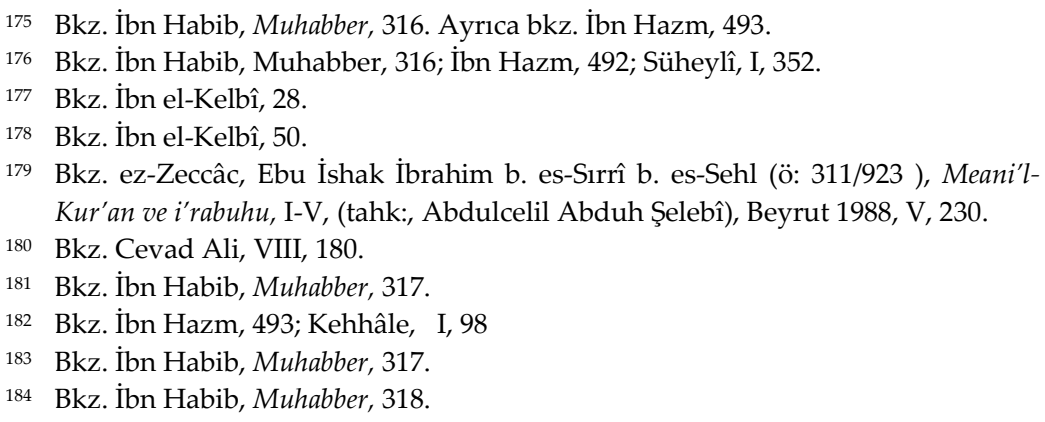


29- Murahhab: Hadramevt bölgesinde yer almakta olup sidaneliği Zu Murahhaboğulları tarafından yapılıyordu. Kabile bu adı söz konusu puttan dolayı almıştı. ${ }^{185}$ Ona ziyarete gelenler telbiyelerinde "lebbeyk lebbeyk, biz senin huzurundayı. Lebbeyk senin için geldik" diyorlard1. ${ }^{186}$

30- el-Muntabik: Sülf, Akk ve Eş'ar kabilelerine ait olup bakırdan yapılmıştı. Karnından farklı seslerin geldiği ve bu seslerin hiçbir sedaya benzemediği iddia edilmektedir. Hz. Peygamber'in emriyle yıkıldığında içinden bir kılıç çıkarılmıştır. Putu yapan kişinin akustiği sağlamak için böyle bir düzenek kurduğu anlaşılmaktadır. El-Muntabık'ın karnından çıkarılan bu kılıç, safiyy hakkı olarak Hz. Peygambere tehdiye edilmiştir. ${ }^{187}$

31- Zülkeffeyn: Huzaa ve Devs kabilesinin tanrısıdır. ${ }^{188} \mathrm{~Hz}$. Peygamber'in emriyle et-Tufayl b. Amr ed-Davsî tarafından yıkılmiştır. ${ }^{189}$

32- Zuşşara: Ezd kabilesinden el-Haris b. Yeşkuroğullarına ait bir puttur. ${ }^{190}$

33- Riam: Himyerlilere ait bir mabed olup San'a'da yer alıyordu. Himyerliler kendisine ihtiram eder ve yanında kurbanlar keserlerdi. İçinden seslerin geldiği rivayet edilmektedir. Bu mabedin Medineli iki hahamın isteği üzerine Tuba' tarafından yıkıldığı mervidir. ${ }^{191}$ Ezd kabilesi de Riam'a ibadet ediyordu. ${ }^{192}$

34- Nuhm: Müzeyne kabilesinin putu olan Nuhm'un sidaneliğini bu kabilenin alt kollarından biri olan 'Abdaoğulları yapmaktaydı. İnsanlar çocuklarına Nuhm'un kulları anlamında Abdunuhm adını vermekteydiler. ${ }^{193}$

35- Âim: Ezd Kabilesinin büyük boyu Ezdu Surat'a ait olan bir puttur. ${ }^{194}$

\footnotetext{
185 Bkz. İbn Habib, Muhabber, 318; İbn Hazm, 493; Cevad Ali, XI, 285.

186 Bkz. Feyyumî, 431.

187 Bkz. İbn Habib, Muhabber, 318.

188 Bkz. İbn Habib, Muhabber, 318; ayrıca bkz. İbn Hazm, 494; Cevad Ali, XI, 283.

189 Bkz. İbn el-Kelbî, 41.

190 Bkz. İbn el-Kelbî, 41.

191 Bkz. İbn el-Kelbî, 29; Ayrıca bkz. İbn Hişam, Sire, I, 87; Cevad Ali, XII, 22.

192 Bkz. Feyyumî, 431.

193 Bkz. İbn el-Kelbî, 42.

194 İbn el-Kelbî, 43.
} 
36- Suayr: Anze Kabilesinin putudur. Bir metaf alanına sahipti. Anze kabilesi, onu tavaf eder ve yanında kurbanlarını keserlerdi. ${ }^{195}$

37- Umyanis: Havlan bölgesinde olup o yörede bulunan halkın tanrısı idi. Rivayetlere göre Havlanlılar, hayvanları ile ekinlerinden bir kısmını Allah ile onun arasında üleştirirlerdi. Sonra Allah'ın payından alarak, onun payına ilavelerde bulunurlardı. Enam suresi 136. ayetinin onun hakkında nazil olduğu rivayet edilmektedir. ${ }^{196}$ “Allah'ın yarattığı ekinlerle Allah'a pay ayırıp zanlarınca, bu Allah'a bu da ortaklarımıza (putlarımıza) dediler. Ortakları için ayrılan Allah'a ulaşmıyor, fakat Allah için ayrılan ortaklarına ulaşıyor! Ne kötü hüküm veriyorlar".

38- al-Ya'kub: Tay kabilesinden Cedileoğullarının putudur. Esedoğulları onların bu putlarını ellerinden alınca onlar da kendilerine "el-Ya'bûb" adında bir put edinmişlerdir. ${ }^{197}$

39- el-Bâcâr: Ezd, Tay ve Kudaa kabileleri tarafından tapılan bir puttur. ${ }^{198}$

40- Kuayb: Cahiliye dönemi putlarından biridir. ${ }^{199}$

41- Teym: Temim kabilesinin putlarından biridir. Bu kabileden birçok şahıs onun adını Abduteym (Teymin Kulu) şeklinde çocuklarını vermekteydi. ${ }^{200}$

42- Medân: Hicaz Araplarının putlarından biridir. ${ }^{201}$

43- Necranlıların Kâbesi: Haris b. Ka'b oğullarına ait olan bu mekânının Kâbe'ye öykünülerek inşa edildiği anlaşılmaktadır. Keza İyadoğullarına ait -daha sonra Kufe ile Basra'nın kurulacağı bölgelerin arasında "Sindâd" denilen bir kıblegâhın olduğu rivayet edilmektedir. ${ }^{202}$

Yukarıda saydığımız bu putların yanında Araplar tarafından tapılan Teym, el-Asham, el-Eşhel, Evvâl, el-Becce, Cureyş, Cihâr, eş-

\footnotetext{
195 İbn el-Kelbî, 43.

196 İbn el-Kelbî, 44.

197 İbn el-Kelbî, 53. Ayrıca bkz. Cevad Ali, XI, 279.

198 Bkz. İbn el-Kelbî, 53; Cevad Ali, VIII, 33; Cevad Ali, XI, 286.

199 Bkz. Ezrakî, I, 140; Himyeri, 468.

200 Bkz. Cevad Ali, XI, 282.

201 Cevad Ali, XI, 285.

202 Bkz. İbn el-Kelbî, 45.
} 
Şaruk, Sumudâ, Ab’ab, Avd, Kays, Fezeh gibi daha pek çok put bulunmaktayd1. ${ }^{203}$

\section{Sonuç}

İslam öncesi Arap toplumunda "Allah" inancının söz konusu olduğu bilinmektedir. Ancak bu "Allah" tasavvuru, M. Eliade'nin tanımıla "deus otiosus" mesabesinde idi. Deus otiosus tanımı, yaratıcı mutlak tanrının yeryüzünden ve kullarından oldukça uzak bir âleme çekilen, kullarının kendisine ulaşmasını güçleştiren ilahi bir konumu ifade etmektedir. Böylesi bir ilahi mercii ile kulluk ilişkisinin kurulması ancak birtakım unsurların yardımını ve aracılığını gerektirdiği düşünülmüştür. Dolayısıyla Cahiliye dönemi Arap toplumu da ilahi mercii ile bu tür temas kurma sürecinde ihdas ettikleri aracı unsurlar çerçevesinde kapsamlı bir putperestlik geleneği inşa etmişlerdir.

Cahiliye Arabı söz konusu putları tanının egemenlik alanı içerisinde, onun tanıdığı yetkiyi kullanan varlıklar olarak görmekteydiler. Yeryüzünde "Allah" 1 temsil eden, adeta onun adına tasarrufta bulunan putlar, onun neredeyse bu görüngü âleminde "eli" mesabesinde idiler. Onların memnun edilmesiyle Allah'ın ancak memnun edilebileceğine inanan cahiliye Arabı, onlara hediyeler takdim eder, kurbanlar keser, etrafında tavafta bulunur, adak adar, adına yemin eder, cünüp ve hayızlı iken huzuruna çıkmaz, ihtiramda kusur etmez, hatta bulundukları mekâna hacca da giderdi. Yaratıcı olarak kabul edilmemekle beraber tanrının tüm sıfatlarına sahip olan putların bir kısmı ise Allah'ın kızları olarak görülürlerdi. Ticaret ile putperestliğin iç içe girdiği cahiliye döneminde putların tamamının birer örneği Kâbe'ye konulmuş ve bu kutsal mekân bir panteona dönüştürülmüştür. Bu durum Mekke'yi dönemin en önemli ticaret merkezi haine de getirmiştir.

\section{Kaynakça}

Abdullah Abdulcebbâr-Muhammed Abdulmünim Hafacî, Kıssatu'l-edeb fi'l-Hicâz, Misır ?.

Ahmed İbrahim eş-Şerif, Mekke ve Medine fi Cahiliyye ve ahdi Resulillah (sav), Daru'l-Fikr el-Arabî, ?.

Ali et-Tantavî (ö:1290/1873), Nihâyetu'l-icâz fi sireti sakini Hicâz, Kahire 1419.

203 Bkz. Cevad Ali, XI, 282; Feyyumî, 430 vd. 
Âlûsî, Muhammed Şükrî, Buluğu'l-ereb fi ma'rifeti ahvâli'l-Arab, (neşr: Muhammed Behcet el-Eserî), I-III, Beyrut?.

Aynî, Bedreddin (ö: 855/1451), Umdetu'l-kari şerh Sahîh el-Buharî, I-XV, Beyrut?.

Beğavî, Ebu Muhammed el-Hüseyin b. Mesud b. Muhammed b. el-Ferrâ (ö:510/1116 ), Mealimu't-tenzil fi tefsiri'l-Kur'an, I-V, (tahk: Abdurrezak Mehdi), Beyrut 1420.

Bureyk b. Muhammed Bureyk el-Umerî, es-Sereya ve'l-buûs en-Nebeviyye Havle el-Medine ve Mekke, Daru İbn el-Cevzî, ? 1996.

Celalettin es-Suyutî, Abdurrahman b. Ebubekir (ö:911/1505), Hasaisu'1kübra, I-II, Beyrut?.

Cevad Ali, el-Mufassal: Tarihu'l-Arab kabl el-İslam, I-XX, Bağdat 2001.

Diyarbekrî, Hüseyin b. Muhammed b. el-Hasan (ö: 966/1558), Tarihu'l-hamis fi ahvâli enfesi'n-nefis, I-II, Beyrut, ?.

Ebû Şame, Ebu'l-Kasım Şihabuddin Abdurrahman b. İsmail b. İbrahim (ö:665/1266), İbrâzu'l-mânî min birzi'l-emâni fi kıraati's-sab'a, Beyrut, ?.

Ezrakî, Ebu'l-Velid Muhammed b. Abdullah b. Ahmed (ö:250/864), Ahbaru Mekke ve ma cae fiha mine'l-âsâr, I-II, (tahk: Ruşti es-Salih), Beyrut, ?.

Himyerî, Ebu Abdullah Muhammed (900/1494), Revdu'l-mi'taf fi haberi aktar, Beyrut 1980.

Hüseyin Atay, "İslam'dan Önce Arap Yarımadasında Putperestlik ve Yay1lışı", Ankara Üniversitesi İlahiyat Fakültesi Dergisi, I-IV: 1957, Ankara 1959.

İbnu'l-Esîr, İzzuddin Ebu'l-Hasan Ali b. Muhammed (ö:630/1232) Usdu'1ğâbe fi ma'rifeti's-sahâbe, I-V, Tahran 1286.

İbn İshak, Muhammed b. İshak (ö:150/767), Siretu İbn İshak, (tahk: Süheyl Zekkâr), Beyrut 1978.

İbn Habib, Muhammed b. Habib, Ebu Ca'fer (ö:245/859), Kitabu'l-muhabber, (tahk: İlse Lichtenstadter), Beyrut Daru'l-Daru'l-Afâk el-Cedîd, ?.

İbn Hacer el-Askalanî, Fethu'l-Barî şerh sahih el-Buharî, I-XIII, Beyrut 1379. İbn Hazm (ö:456/1063), Cemheretu ensâbi'l-Arab, (tahk: Komisyon), Beyrut 1983.

İbn Hişam (ö:218/833), Siretu İbn Hişam, I-II, (tahk: Mustafa Saka-İbrahim Ebyarî-Abdulhafız Şelebî), Beyrut 1955.

İbn Hişam (ö:218/833), et-Ticân fi muluki Himyer, Yemen 1347.

İbn el-Kelbî (ö:204/819), Putlar Kitabı, (terc: Beyza Düşüngen), Ankara 1969.

İbn Kesir, Ebu'1-Fida İsmail b. Ömer (ö:774/1372), Tefsiru İbn Kesîr, I-VIII, (tahk: Sami b. Muhammed Sellâme), Daru't-Tayyibe, ? 1999.

İbn Sa'd, Tabâkatu'l-kubrâ, I-IX, Beyrut?. 
İz b. Abdusselam, Ebu Muhammed İzzuddin (ö:660/1261), Tefsiru'1-Kur'an, I-III, Beyrut 1996.

Kilâî, Süleyman b. Musa b. Salim (ö: 634/1236), el-i̇ktifa fi meğazi Resulillah ve selâseti hulefa', I-II, Beyrut 1420.

Kurtubî, Ebu Abdullah Muhammed b. Ahmed b. Ebubekir b. Ferah el-Ensarî (ö:671/1272), el-Câmi' li Ahkami'l-Kur'an, I-XX, (tahk: Ahmed el-Berdunî ve İbrahim İtfiş), Kahire 1964.

Makrizî, Ahmed b. Ali b. Abdulkadir, Takiyuddin (ö: 845/1441), İmtau'1esma' bima li'n-nebî mine'l-ahvâl ve'l-emvâl ve'l-hafede ve'l-meta', I-XV, (tahk: Muhammed Abdulhamid en-Nemisî), Beyrut 199.

Maverdî, Ebu'l-Hasan Ali b. Muhammed b. Muhammed (ö:450/1058), A'lamu'n-Nubuvve, Beyrut 1409.

Meriî, el-Muhelleb b. Ahmed b. Ebî Sufra (ö:435/1043), el-Muhtasaru'1-nasîh fi tezhibi kitabi'l-camii's-sahîh, I-IV, (tahk: Ahmed b. Faris esSelûm), Riyâd 2009.

Mesudî, Ebu'l-Hasan Ali b. Hasan (ö: 346/), Ahbaru'z-Zaman, Beyrut 1996.

Muhammed İbrahim el-Feyyumî, Tarihu'l-fikr ed-dinî el-Cahilî, Daru'lFikr el-Arabî, Beyrut 1994.

M. J. Kister, "Some Reports Concerning Mecca From Cahiliyye to İslam”, JESHO, Brill, Leiden 1972.

Nevevî, Ebu Zekeriyya Muhyiddin Yahya (ö:676/1277), el-Minhâc fi şerh sahih Müslim b. el-Haccâc, I-XVIII, Beyrut 1392.

Ömer Rıza Kehhâle, mu'cemu kebâilu'l-Arab, I-V, Beyrut 1982

Razî, İbn Ebî Hatem Ebu Muhammed Abdurrahman b. Muhammed b. İdris b. Münzir et-Temimî (ö: 327/938), Tefsiru'l-Kur'ani'l-azîm, (tahk: Es'ad Muhammed et-Tayyîb), Riyad 1419.

Sa'lebî, Ahmed b. Muhammed b. İbrahim (ö: 427/1035), el-Keşf ve'l-beyân an tefsiri'l-Kur'an, I-X, (tahk: İmam Ebu Muhammed b. Âşûr), Beyrut 2002.

Suheylî, Ebu'l-Kasım Abdurrahman b. Abdullah (ö:581/1185), er-Revdu'1unf fi şerhi's-sireti'n-Nebeviyye li İbn Hişam, I-VII, (tahk: Ömer Abdusselâm), Beyrut 2000.

Şamî, Muhammed b. Yusuf es-Salihî (ö: 942/1535), Subulu'l-huda ve'r-reşâd fi sireti hayri'l-ibâd ve zikri fedailihi ve a'lami nubuvetihi ve ef'alihi ve ahvâlihi fi'l-mebdei ve'l-mead, I-XII, (tahk: Adil Ahmed Abdulmevcud-Ali Muhammed Muavvad), Beyrut 1993.

Taberî, Muhammed b. Cerir (ö: 310/922), Tarihu'l-umem ve'l-mulûk, I-XI, Beyrut 1387.

Taberî, Muhammed b. Cerîr, Camiu'l-beyân fi Te'vili'l-Kur'an, I-XXIV, (tahk: Ahmed Muhammed Şakir), Beyrut 2000.

Yakut el-Hamevî, Şihabuddin Ebu Abdullah (ö:626/1228), Mu'cemu'1buldân, I-VII, Beyrut 1997. 
Mehmet Mahfuz SÖYLEMEZ

Zamahşerî, Carullah Ebu'1-Kasım Mahmud b. Amr b. Ahmed (ö: 538/1143), el-Keşşâf an hakaiki cevamidi't-tenzil, I-IV, Beyrut 1407.

Zeccâc, Ebu İshak İbrahim b. es-Sırrî b. es-Sehl (ö: 311/923 ), Meani'l-Kur'an ve i'rabuhu, I-V, (tahk:, Abdulcelil Abduh Şelebî), Beyrut 1988.

Zehebî, Şemsettin Ebu Abdullah Muhammed b. Abdullah b. Osman b. Kaymaz (ö: 748/1347), el-Munteka min minhâci'l-i'tidâl fi nakdi kelâmi ehli'r-refdi ve'l-i'tizâl, (tahk:, Muhyiddin el-Hatib), ?. 


\section{MiLel VE NiHAL}

inanç, kültür ve mitoloji araştırmaları dergisi

Cilt/Volume: 11 Sayı/Number: 1 Ocak - Haziran / January - June 2014 ISSN: 1304-5482

Bu dergi uluslararası EBSCO HOST Research Databases veri indeksi ve TÜBITTAK-ULAKBİM Sosyal ve Beşeri Bilimler Veri Tabanı tarafından taranmaktadır.

\section{Sahibi / Owner}

Milel ve Nihal Eğitim, Kültür ve Düşünce Platformu Derneği adına Şinasi Gündüz

$$
\begin{gathered}
\text { Yazı İşleri Sorumlusu / Legal Representative } \\
\text { Yasin Aktay }
\end{gathered}
$$

\section{Editör / Editor}

Şinasi Gündüz

Editör Yrd. / Co-Editor

Cengiz Batuk

\section{Yayın Kurulu/ Editorial Board*}

Alpaslan Açıgenç, Ayaz Akkoyun, Yasin Aktay, Mahmut Aydın,

Cengiz Batuk, Şinasi Gündüz, İbrahim Kayan, Hakan Olgun, Necdet Subaşı,

\section{Burhanettin Tatar}

\section{Danışma Kurulu/Advisory Board}

Baki Adam (Prof. Dr., AÜ); Mohd. Mumtaz Ali (Prof. International Islamic U. Malezya); Adnan Aslan (Prof.Dr., Süleyman Şah Ü.); Kemal Ataman (Doç.Dr., Uludağ Ü.); Mehmet Akif Aydın (Prof. Dr., Marmara Ü.); Yılmaz Can (Prof. Dr., OMÜ); Ahmet Çakır (Doç. Dr., OMÜ); Mehmet Çelik

(Prof. Dr., Celal Bayar Ü.); Waleck S. Dalpour (Prof. University of Maine at Farmington); İsmail

Engin (Dr., Berlin); Cemalettin Erdemci (Prof.Dr. YYÜ); Tahsin Görgün (Prof.Dr., 29

Mayıs Ü.) Ahmet Güç (Prof.Dr., Uludağ Ü.); Recep Gün (Doç. Dr., OMÜ); Ö. Faruk Harman

(Prof.Dr., Mar.Ü.); Erica C.D. Hunter (Dr., Cambridge U.); Mehmet Katar (Prof. Dr., A.Ü.);

Mahmut Kaya (Prof. Dr., İ.Ü.); Sadık Kılıç (Prof.Dr., Atatürk Ü.); Şevket Kotan (Y.Doç.Dr., İ.Ü.); İlhan Kutluer (Prof.Dr., Mar. Ü.); George F. McLean (Prof. Catholic Univ., Washington DC); Ahmet Yaşar Ocak (Prof. Dr., Hacettepe Ü.); Jon Oplinger (Prof. University of Maine at Farmington); Ömer Özsoy (Prof.Dr., Frankfurt U.); Roselie Helena de Souza Pereira (Mestre em

Filofia-USP; UNICAMP Brasil); Ekrem Sarıkçıŏlu (Prof.Dr., SDÜ); Hüseyin Sarıŏlu (Prof.Dr.,

İÜ); Bobby S. Sayyid (Dr. Leeds U.); Mustafa Sinanoğlu (Prof.Dr., 29 Mayıs Ü.); Mahfuz Söylemez

(Prof.Dr. IÜ); Necdet Subaşı (Y.Doç.Dr., DİB); Bülent Şenay (Prof.Dr., UÜ); İsmail Taşpınar

(Prof.Dr. Mar.Ü.); C. Sadık Yaran (Prof.Dr., OMÜ); Ali Murat Yel (Prof.Dr., Fatih Ü.); Hüseyin Yılmaz (Doç.Dr., YYÜ); Ali İhsan Yitik (Prof. Dr., DEÜ)

* Soyadına göre alfabetik sıra / In alphabetical order

Kapak ve Sayfa Tasarımı / Cover \& Page Design

İnan Avc1

Baskı / Publication

Ladin Ofset - İstanbul, Mart 2015

2.Mat. Sit. 3 NB 15 Topkapı İstanbul / İsmail Tüz 02125012418

Yönetim Yeri / Administration Place

Milel ve Nihal Eğitim, Kültür ve Düşünce Platformu Derneği

Fevzipaşa Cad. Şehit Mehmet Sarper Alus Sok. No: 5, K.: 3, Tel: (0212) 5339731 Fatih/İstanbul www.milelvenihal.org e-posta: dergi@milelvenihal.org

Milel ve Nihal yılda iki sayı olarak altı ayda bir yayımlanan uluslararası hakemli bir dergidir. Milel ve Nihal' de yayımlanan yazıların bilimsel ve hukuki sorumluluğu yazarlarına aittir. Yayım dili Türkçe ve İngilizce'dir. Yayımlanan yazıların bütün yayın hakları Milel ve Nihal'e ait olup, yayıncının izni olmadan kısmen veya tamamen basılamaz, çoğaltılamaz ve elektronik ortama taşınamaz. Yazıların yayımlanı yayımlanmamasından yayın kurulu sorumludur. 


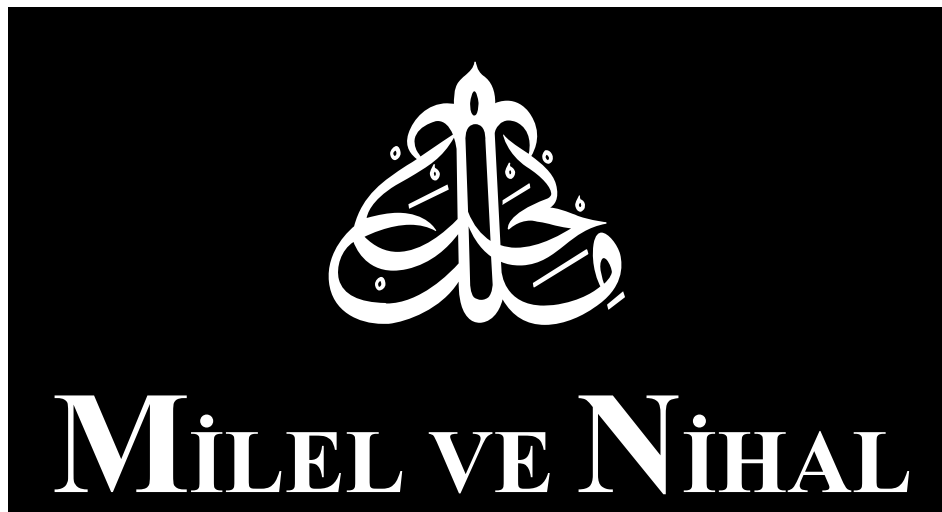

inanç, kültür ve mitoloji araştırmaları derogisi

ISSN: 1304-5482

Cilt/Volume: 11 Sayı/Number: 1

Ocak - Haziran / January - June 2014 